
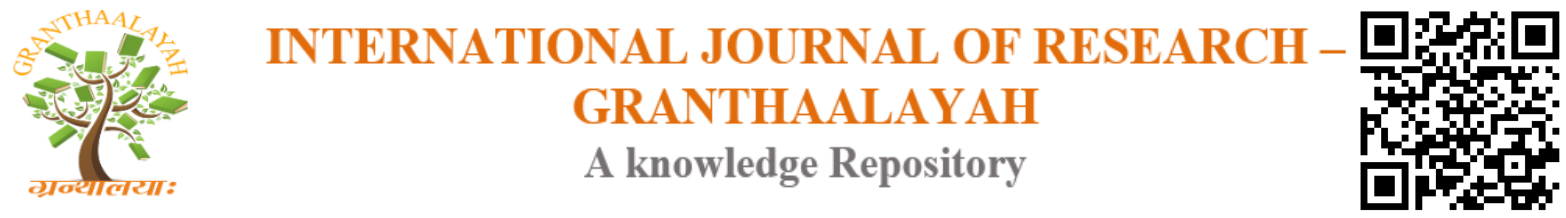

Management

\title{
ATTRACTIVENESS OF TOURISM INDUSTRY IN CALABARZON: INPUTS TO BUSINESS OPERATIONS INITIATIVES
}

\author{
Elroy Joseph C. Valdez ${ }^{* 1,2}$ \\ ${ }^{* 1}$ College of Accountancy, Business, Economics and International Hospitality Management, \\ Batangas State University, Philippines \\ ${ }^{2}$ College of International Tourism and Hospitality Management, Lyceum of the Philippines \\ University - Batangas, Philippines
}

\begin{abstract}
This study will identify the attractiveness of tourism in CALABARZON. More specifically: it will to evaluate the level of attractiveness of tourism industry in CALABARZON in terms of cultural proximity, destination environment, price, destination image, risk and reward, and geographical proximity; to test if investment climate significantly affects attractiveness of tourism industry in CALABARZON; to propose a tourism development plan based on the results. The researcher used descriptive method to determine the investment climate and attractiveness of tourism industry in CALABARZON. The questionnaire is one of the major instruments used by the researcher to gather and collect the needed data. Results showed that majority of the respondents belonged to the young age group, female, single, college graduate and has an average income. The tourists, local residents and local government unit all agreed that CALABARZON region is moderately attractive to tourists due to competitors of tourist destination on the good services provided among them. Investment climate has an effect on the attractiveness of the tourism industry in CALABARZON region. The researcher proposed business operations initiative win order for the tourism industry in CALABARZON region more competitive.
\end{abstract}

Keywords: Attractiveness; Cultural Proximity; Destination Environment; Price; Destination Image; Cultural Proximity.

Cite This Article: Elroy Joseph C. Valdez. (2019). "ATTRACTIVENESS OF TOURISM INDUSTRY IN CALABARZON: INPUTS TO BUSINESS OPERATIONS INITIATIVES." International Journal of Research - Granthaalayah, 7(4), 225-254. https://doi.org/10.29121/granthaalayah.v7.i4.2019.894.

\section{Introduction}

Tourism as arena's largest industry and the fastest developing enterprise. It is also a totally dynamic enterprise which had a reply to a wide variety of factors outside its manipulate. As one of the most modern industries it impacts on almost each different enterprise and in particular critical in regional areas because it diversifies the region as financial base and increase the employment market in its 
broadest experience, (Bhatia, 2014). Tourism therefore, is outstanding from a principle of enjoyment and pastime on one hand, and from tour and migration alternatively, (Cruz, 2011).

The Philippine Department of Tourism (DOT) was tasked to inspire, sell, and develop Philippine tourism as a main socio-financial hobby geared to producing overseas forex and employment and to unfold the advantages of tourism to a wider section of the populace. The local development Plan for Southern Tagalog (Region IV) gives the muse and direction for the authorities and the private quarter in growing the tourism industry within the place anchored in the sights in order to be evolved, improved and promoted. (Tamayo and Celis, 2006)

CALABARZON has all built its distinctive reputation among tourists. Laguna, being the "Resort Capital of the Philippines," has undoubtedly won the hearts of local and global tourists alike with its robust strings of hot-spring resorts and swimming-pool attractions. Cavite has inevitably positioned itself as "Historical Capital of the Philippines," as the province was literally the home of the Philippine Declaration of Independence from Spanish colonial rule dating back to 1898 . Batangas is known to have the second-largest international seaport in the Philippines, and one of the nearest getaway destinations with its rich, stunning beach attractions that are just three hours away from Metro Manila. Rizal is famous for its mountainous ranges that offer a panoramic view of Metro Manila in its urbanized spots in Antipolo, while Quezon province takes pride in its attributes that offer amazing faith tours, from its spiritual and mystical attractions that is Mount Banahaw, to grand festive fiesta treats, like the beautiful Pahiyas Festival every month of May.

There are lot of tourist destinations in CALABARZON. In Cavite, Cabang cave in Maragondon is one in every of vacationer spots in Cavite. The cave with an underground river that runs 50 meters inward is discovered amidst lush foliage on the foot of a steep slope. A brook forms a small pool at the mouth of the cave, (Lubiano, 2016).

Malibiclibic Falls is an end result of a convergence between 3 rivers flowing from Magallanes, Aguinaldo, and Maragondon, Cavite. To which due to hundreds of thousands of years of the three rivers pounding a 100-meter excessive cliff, the water found its manner thru it; as a result creating a waterfall. The Malibiclibic Falls may be accessed via strolling thru a 1.2-kilometer $4 \times 4$ trail from the Maragondon-Aguinaldo country wide avenue. From the graze land, to a slippery soil and mossblanketed boulders; trail down to the falls isn't that clean as the falls is seldom accessed via hikers. The trek is set 612 meters and approximately a hundred meters down, (Malibiclibic Falls, A Hidden Falls below the grasslands of Cavite, 2013)

In Laguna, Pagsanjan Falls is majestically descending in a captivating place, it's far one of the earliest vacationer spots in the Philippines, brought to outdoor global by using an American missionary who visited it in 1902. It turned into he who first posted the name 'Pagsanjan Falls', despite the fact that its unique name become Magdapio Falls. The call Pagsanjan comes from the Tagalog word "Pinagsangahan" which means "where it branches". This refers back to the branching off of the two rivers, Bumbungan and Balanac. (Henares, 2007)

In Batangas, the very energetic Taal Volcano lies in the southern part of Luzon Island best $60 \mathrm{~km}$ from Manila, the capital of the Philippines. The northern part of Volcano Island falls below the jurisdiction of the lake shore city of Talisay, and the southern half of to San Nicolas. the opposite 
groups that encircle Taal Lake encompass the towns of Tanauan and Lipa, and the municipalities of Talisay, Laurel, Agoncillo, Santa Teresita, Alitagtag, Cuenca, Balete and Mataas na Kahoy. In fact, it has the recognition of being the sector's smallest energetic volcano, taking simplest about forty-five minutes to attain the island by using a boat, and every other 20 extraordinary minutes to reach the summit of the volcano. The island fashioned because of the repeated volcanic eruptions has genuinely been named Volcano Islands and it nearly a place of 23 sq. kilometers. everlasting settlements have, even though, been prohibited by way of PHIVOLCS, or the Philippine Institute of Volcanology and Seismology, as the dangers related to eruptions are constantly chronic. despite the warnings, terrible families have made this island their home, and earn a dwelling by means of farming crops within the rich and fertile volcanic soil. (You et. al., 2012)

In the fine seaside in Tingloy, Masasa Beach was located. It is an island fish-shaped in Maricaban, off the tip of Calumpang Peninsula keeping apart Balayan Bay from Batangas Bay. The white sand even not pearly compared to Boracay or Palawan, has its brightness of its sand which makes up for in the vibrance of waves. Its crystal clean, shallow waters provide off a beautiful turquoise shimmer that capture your attention even from a notable distance. (Masasa Beach on a Budget: Travel Guide \& Itinerary, 2017)

In Mabini, Batangas, famous is the Sombrero Island which could be reached by using boat from the shore of Anilao for about half an hour. The island has been named as such as it resembles a hat underwater. A small stretch of beach can be found on this island. It has a pearly white sand with smooth and clear water. subsequently, this island turns into a favourite side trip amongst folks that climb the close by mountains. Boat apartment attending to the island fees around php 2,500.00 that may match for approximately 10 folks. front charge to the island additionally wishes to be paid upon arrival which charges php 150.00 consistent with individual. There also are cottages available for comfortable stay. The island is simply small with white sand and few small rocks that would hurt a bare foot while you stroll through the shore. (Velasco, 2013)

Mabini is now a traveller Paradise. The municipality is blessed with plenty of marine life- fishes, sea turtles, whales, dolphins and corals - a domain to behold for scuba divers, foreign and local alike. aside from the travelers, individuals of the community consisting of the fisher parents, motel employees, and boat operators rely on the cultured cost of those assets. At gift, Mabini is innovative in terms of socio-financial boom. Strategically located with world-elegance lodging placed inside the obstacles of Anilao, Batangas, Halo Anilao Dive hotel are proud to provide its services to its elite magnificence of shoppers from round the arena. (Abella et. al., 2014)

One of the most popular mountain destinations on the south of the capital metropolis of Manila in the Philippines is Maculot, as a substitute Mount Macolod. it's miles located in the Municipality of Cuenca, Batangas and has coordinates of $13^{\circ} 55.241^{\prime} \mathrm{N}$ latitude and $121^{\circ} 02.513^{\prime} \mathrm{E}$ longitude. The mountain is set $947 \mathrm{~m}$ (three, 107 toes) in altitude and is positioned adjacent to Taal Lake (Arsenio et.al., 2011). consistent with studies, Mount Maculot and its seven hundred-metre (2,three hundred $\mathrm{ft}$ ) high volcanic rock wall known as The Rockies, is said to be part of Taal Caldera's crater rim (Mount Macolod, 2008).

As an ecotourism enchantment, Mount Maculot is famous among mountain climbers and campers. it's miles a fave because of its well-established trail, extensive camp grounds, excellent views atop 
and simply enough diploma of trouble in hiking. Its principal appeal is The Rockies, a rocky outcropping overlooking Taal Lake and its well-known Taal Volcano. It takes a bit of rock climbing competencies to reach the pinnacle of the Rockies, however simply, the effort is properly rewarded via the breathtaking vista above it. The Camp website online is placed atop the mountain's shoulder. it's miles generally busy on weekends and there is not plenty privacy. The wind is moderate to sturdy and pretty cold at night. The Summit is every other hour faraway from the camp web page, despite the fact that an opportunity path, the Grotto trail, can be taken, traversing the mountain from the alternative facet and then descending to the shoulder camp website online. (Dalisay, 2015)

In contrast to different mountains, Mt. Pamitinan offers a difficult yet clean trail for first-time hikers. Its peak is $426+$ meters above sea level (MASL), and it takes kind of an hour and a half of to three hours until you reach the summit. With a trouble level of three, this mountain in Rodriguez, Rizal, permits you to discover and unharness your internal strength with its steep trails and pointed rock formations. The climb is conceivable but will honestly require whole attention and care. (Casupanan, 2017)

A gem at the heart of the superb Sierra Madre mountain range, near sufficient to Manila to do as a dayhike, is Mt. Daraitan, which sits near the border of Tanay, Rizal and popular Nakar, Quezon. A former logging area, the village that bears the mountain's name is now an ecotourism web page that offers outdoor points of interest such as caves, springs, herbal swimming pools, and limestone formations. A version for ecotourism, the barangay has an organised machine for handling traffic, including skilled local publications. The hike up is a (normally) truthful six hundred-meter ascent that might experience steep to those no longer used to hiking. There are, however, plenty of holds and the trail is properly-maintained. The forest environment is similar in characteristics with Mt. Pinagbanderahan, which also lies within the Sierra Madre - but Daraitan has more profitable limestone viewpoints and a miles extra tough hike. (Lasco, 2014)

The Masungi Georeserve is a conservation location and a rustic rock lawn tucked in the rainforests of Rizal. Masungi's call is derived from the phrase "masungki" which translates to "spiked" - an apt description for the sprawling limestone panorama found within. in this sanctuary, guests can be able to commune with nature, and reenergise themselves whilst doing so. Wander via our pathways for an come upon with natural world and plant species. experience mild snacks earlier than exiting the path. analyze greater about the history of the region introducing you to a community wealthy with historical past and lifestyles. (Masungi Georeserve, 2018)

The shore line of Salibungot beach is painted with a golden pleasant sand that in reality make it specific. Its golden sand complements the crystal turquoise water. Locals friendly makes this area a package for a total get away from the bustle town existence. Salibungot seaside sits eighty-two kilometers faraway from the shore of real inside the province of Quezon. it is coastline sits in the southwestern edge of Jomalig island dealing with the Lamon Bay of Polilio organization of island. it is crystal clean turquoise blue sea water is best for snorkeling or absolutely playing a swim. whilst pine trees that provides herbal color is perfect to just loosen up and experience the cool breeze of the Pacific Ocean. And Salibungot golden first-class sand is best for a few sand interest however laying without a mat isn't advocated. Sand mite is lurking below its lovely golden pleasant sand. This tiny monster is the simplest downfall of this paradise. (Balaoing, 2017) 
The Kanaway beach is placed at Sitio Petisan of Barangay Apad, the easternmost facet of Jomalig island this is going through the brink of Pacific Ocean, just beside the Kanaway River. The seaside is composed of huge golden sands stretching to about four hundred meters from the shore with close by islets which might be handy by means of foot throughout low tide or a brief wade or swim on excessive tide. The sand has herbal ripple formations which is a charming sight to behold. The golden sand characteristic is due to the corals ample near its seashores referred to as Acropora caroliniana. The seashore is included with the aid of corals and stone formations approximately 700 meters away from the shore which blocks robust waves from the Pacific Ocean. (Kanaway: The Sunrise Beach of Jomalig Island, 2013)

The study has identified top 10 tourist destinations in each provinces and group it according to classification. Since majority of the top 10 are natural attractions, the study focused on that aspect. The selected tourist destinations are Cabang cave and Malibic Libic Falls in Cavite, Pagsanjan Falls and Dalitiwan Falls in Laguna, Taal Volcano, Masasa Beach, Sombrero Island, Laiya Beach, Anilao Dive Sites and Mt. Maculot in Batangas, Daranak Falls, Mt. Pamitinan, Mt. Daraitan and Mt. Masungi in Rizal and Salibungot beach and Kunaway beach in Quezon.

With this, attractiveness of the region is not questionable however maintaining its popularity in terms of attractiveness is the major challenge. This attractiveness will be sustained through collaborative effort of the stakeholders of the tourism industry. Hence, government support to is necessary to attain such objective. The more favorable projects provided by the government for the industry, the more it will be attractive. On the other hand, in case government cannot provide other support services to the industry, private entities may intervene. This can be attain through investment. However, private investors need to consider the attractiveness of the region in terms of investment which is covered by the concept on investment climate.

\section{Materials and Methods}

The study used descriptive method which focuses at present condition in the purpose to find new truth. This was used to determine attractiveness of tourism industry in CALABARZON. The questionnaire is one of the major instruments used to gather and collect the needed data.

The subjects of the study are tourists, local residents and LGU particularly those offices who are engaged in the tourism industry. They are chosen as the participants because they have enough knowledge about the status of the investment climate and the attractiveness of the tourism industry in their respective areas. The study utilized 390 respondents which was from the total population of local residents, total tourist arrivals and total number of employees per provincial tourism offices provided by the Philippine Statistical Authority and respective provincial tourism office of each provinces. It made used of stratified proportionate random sampling to distribute properly the number of respondents in each provinces and in each tourist destinations.

\section{Profile of the Respondents}

Table 1 presents the distribution of the respondents in terms of the profile.

It can be gleaned from the table that in terms of age majority of the respondents are in the age bracket of 18-35 years old with a frequency of 256 and a percentage of 65.6. It was followed by 
the age bracket of 36-55 years old with a frequency of 103 and a percentage of 26.4. Lastly, is the age bracket 56 years old and above with a frequency of 31 and a percentage of 7.9. In terms of sex, majority of the respondents are female with a frequency of 204 and a percentage of 52.3 followed by the male with the frequency of 186 and a verbal interpretation of 47.7. In terms of civil status, majority of the respondents are single with a frequency of 208 and a percentage of 53.3, followed by the married with a frequency of 165 and a percentage of 42.3. Lastly, are the widow/ widowed/ separated with a frequency of 17 and a percentage of 4.4. In terms of educational attainment, majority of the respondents are college graduate with a frequency of 185 and a percentage of 47.4, followed by high school graduate with a frequency of 109 and a percentage of 27.9.

In terms of technical/ vocational graduate with a frequency of 71 and a percentage of 18.2, followed by elementary graduate with a frequency of 14 and a percentage of 3.6. Lastly, is the post graduate with a frequency of 11 and a percentage of 2.8. In terms of monthly income, majority of the respondents has an income of Php 10,001.00 - Php 25,000.00 with a frequency of 164 and a percentage of 39.2, followed by below Php 10,000.00. Next is the bracket Php 25,001.00 - Php $50,000.00$ with a frequency of 56 and a percentage of 14.4, lastly is the php 50,001 and above with a frequency of 17 and a percentage of 2.8 .

Table 1: Distribution of the Respondents in terms of their Profile

\begin{tabular}{|l|l|l|}
\hline Profile & Frequency & Percentage \\
\hline Age & & \\
18-35 years old & 256 & 65.6 \\
56-55 years old & 103 & 26.4 \\
\hline Total & 31 & 7.9 \\
\hline Sex & 390 & 100 \\
\hline Male & & \\
Female & 186 & 47.7 \\
\hline Total & 204 & 52.3 \\
\hline Civil Status & 390 & 100 \\
\hline Single & & \\
Married & 208 & 53.3 \\
Widow/ & 165 & 42.3 \\
Separated & 17 & 4.4 \\
\hline Total & & \\
\hline Educational Attainment & & 100 \\
\hline Elementary Graduate & 14 & \\
High School Graduate & 109 & 3.6 \\
Technical/ & 71 & 27.9 \\
Graduate & 185 & 18.2 \\
College Graduate & 11 & 47.4 \\
Post Graduate & & 2.8 \\
\hline Total & 390 & 100 \\
\hline Monthly Income & & 39.2 \\
\hline Below Php 10,000.00 & 153 & \\
& 164 & \\
\hline & & \\
\hline & & \\
\hline
\end{tabular}




\begin{tabular}{|l|l|l|}
\hline Php 10,001.00 - Php & 56 & 14.4 \\
25,000.00 & 17 & 4.4 \\
Php 25,001 - Php 50,000 & & \\
Php 50,001 and above & & 100 \\
\hline Total & 390 & \\
\hline
\end{tabular}

Findings showed that most of the respondents are in the age bracket of 18-35 years old, female, single, college graduate and has a monthly income of Php 10,001.00 - Php 25,000.00 as supported by the data given by the Philippine Statistics Authority, (2017).

The study used questionnaire as the major instrument in gathering the necessary data. The questionnaire was adopted to the study of Islam S., Hossain K and Noor, M. (2017), entitled "Determining Drivers of Destination Attractiveness: The Case of Natured-Based Tourism of Bangladesh". The questionnaire was composed of two parts. Part I contains the profile of the respondents. Part II contains the assessment of government support, investment climate and attractiveness of tourism industry in CALABARZON. The result of the reliability (Chronbach Alpha) was .901 which means that the questionnaire was reliable and can proceed to the actual survey.

Ethical considerations were practiced by the researcher in the conduct of the study to ensure that every information that will be gathered will be used for research purposes only to maintain the quality and integrity of the research. The researcher also seeks the consent of the respondents through letter and communication to make sure that they are prepared to answer necessary questions involved in the research. It was also ensured the confidentiality and anonymity of the respondents by giving them an option to write their names or not in the questionnaire. The researcher also ensured that the respondents voluntarily answer the questionnaires according to their will. Lastly, it was also ensured that none of the respondents of the study got hurt or harmed and their safety and security was of top priority.

The information gathered from the survey were classified, tallied and analyzed. The researcher used the following statistical procedures in analyzing these. Percentage was used to determine profile of the respondents. Weighted Mean was used to answer the objective number one that is to assess the quality of investment climate of tourism industry in CALABARZON and objective number two that is to evaluate the level of attractiveness of tourism industry in CALABARZON. One-way analysis of Variance (ANOVA) was used to determine the significant difference on the assessment of the respondents to quality of investment when grouped according to LGU, residents and tourists. Regression analysis was used to test if investment climate significantly affects attractiveness of tourism industry in CALABARZON.

\section{Results and Discussions}

Table 2 presents the assessment of the tourists and local government on the level of attractiveness of tourism industry in terms of cultural proximity which attained a composite mean of 3.37 with a verbal interpretation of agree. This means that the level of attractiveness of tourism industry in CALABARZON is moderately attractive with the presence of its culture having been enriched through generations and are still practice in the present situation. 
Table 2: Level of Attractiveness of Tourism Industry in terms of Cultural Proximity

\begin{tabular}{|c|c|c|c|c|c|c|c|c|c|}
\hline \multirow[t]{2}{*}{ Cultural Proximity } & \multicolumn{2}{|c|}{ Tourists } & \multicolumn{2}{|c|}{$\begin{array}{c}\text { Local } \\
\text { Residents }\end{array}$} & \multicolumn{2}{|c|}{$\begin{array}{c}\text { Local } \\
\text { Governm } \\
\text { ent }\end{array}$} & \multicolumn{2}{|c|}{$\begin{array}{l}\text { Grand } \\
\text { Mean }\end{array}$} & \multirow[t]{2}{*}{ Rank } \\
\hline & WM & VI & WM & VI & WM & VI & WM & VI & \\
\hline $\begin{array}{l}\text { 1. The local people } \\
\text { has distinct language } \\
\text { spoken almost } \\
\text { everywhere. }\end{array}$ & 3.17 & A & 3.26 & A & 3.67 & SA & 3.36 & $\mathrm{~A}$ & 5.5 \\
\hline $\begin{array}{l}\text { 2. Verbal } \\
\text { communication and } \\
\text { signage instructions } \\
\text { are well represented } \\
\text { by the local dialect of } \\
\text { the place. }\end{array}$ & 3.28 & A & 3.56 & SA & 3.33 & A & 3.39 & A & 4.5 \\
\hline $\begin{array}{l}\text { 3. Religious activities } \\
\text { such as processions } \\
\text { are observable and } \\
\text { well celebrated. }\end{array}$ & 3.26 & A & 3.62 & SA & 3.67 & SA & 3.52 & SA & 3 \\
\hline $\begin{array}{l}\text { 4. Festivals are } \\
\text { celebrated in honor of } \\
\text { their patron saint. }\end{array}$ & 3.28 & $\mathrm{~A}$ & 3.68 & SA & 3.67 & SA & 3.54 & SA & 2 \\
\hline $\begin{array}{l}\text { 5. Bayanihan is well } \\
\text { observed through the } \\
\text { local people. }\end{array}$ & 3.23 & A & 3.47 & A & 3.17 & A & 3.29 & A & 9 \\
\hline $\begin{array}{l}\text { 6. Tourist destinations } \\
\text { offers local delicacies } \\
\text { for the tourists. }\end{array}$ & 3.33 & $\mathrm{~A}$ & 3.48 & A & 3.17 & A & 3.33 & A & 8 \\
\hline $\begin{array}{l}\text { 7. Cultural shows and } \\
\text { presentations are } \\
\text { observable and well } \\
\text { presented. }\end{array}$ & 3.15 & A & 3.32 & A & 3.00 & A & 3.16 & A & 10 \\
\hline $\begin{array}{l}\text { 8. Local foods and } \\
\text { dishes are served to } \\
\text { tourists in restaurants } \\
\text { and hotels. }\end{array}$ & 3.28 & $\mathrm{~A}$ & 3.46 & $\mathrm{~A}$ & 3.33 & A & 3.36 & $\mathrm{~A}$ & 5.5 \\
\hline $\begin{array}{l}\text { 9. Religious churches } \\
\text { are visible and well } \\
\text { maintained. }\end{array}$ & 3.27 & A & 3.72 & SA & 3.17 & A & 3.39 & A & 4.5 \\
\hline $\begin{array}{l}\text { 10. Local made } \\
\text { products especially } \\
\text { handmade products } \\
\text { are available for the } \\
\text { purchase of the } \\
\text { tourists. }\end{array}$ & 3.26 & A & 4.46 & $\bar{A}$ & 3.33 & A & 3.68 & SA & 1 \\
\hline Composite Mean & 3.25 & A & 3.50 & SA & 3.35 & A & 3.37 & A & \\
\hline
\end{tabular}


Legend: 3.50 - 4.00= Strongly Agree/ Highly Attractive; 2.50 - 3.49 = Agree/ Moderately Attractive; 1.50 - 2.49 =Disagree/Less Attractive; 1.00 - $1.49=$ Strongly Disagree/ Not Attractive

In terms of the assessment of the respondents, they strongly agreed that local made products are available for purchase got the highest assessment with a weighted mean of 3.68. They also agreed that Festivals are celebrated in honor of their patron saint" and Local foods and dishes are served to tourists in restaurant and hotels with a weighted mean of 3.54. Meanwhile, cultural shows and presentations are observable and well presented got the lowest assessment with a weighted mean of 3.16 .

Results indicates that having the locally made products available to tourists for purchase will make the CALABARZON region attractive, for most of the tourists that are travelling to different places are always looking for souvenirs which mostly are locally made that served also as memorabilia in their travel. Good quality of local products can attract more tourists for it promotes the culture of the place, local art appreciation and enhancing the local products popularity to different places through the experiences of the tourists.

Culture creates uniqueness and area of expertise in the international tourism market. It this regard, "tourism experiences" that can join people and visitors nearby cultures are very important. In many cases, the theming of destinations is additionally linked to specific cultural occasions (e.g. connected to famous places, human or historical events) which can also play a catalyst role in this development. (The Impact of Culture to Development, 2014)

Table 3 presents the assessment of the tourists, local residents and local government on the level of attractiveness of tourism industry in terms of destination environment which attained a composite mean of 3.44 with a verbal interpretation of agree. This means that the level of attractiveness of tourism industry in CALABARZON is moderately attractive for tourists and local government and highly attractive for local residents for having a good environment in different tourist destinations which offers good ambiance and relaxing atmosphere that are mostly looking of by the tourists.

Table 3: Level of Attractiveness of Tourism Industry in terms of Destination Environment

\begin{tabular}{|l|l|l|l|l|l|l|l|l|l|}
\hline \multicolumn{1}{|c|}{$\begin{array}{c}\text { Destination } \\
\text { Environment }\end{array}$} & \multicolumn{2}{|c|}{ Tourists } & \multicolumn{2}{c|}{$\begin{array}{c}\text { Local } \\
\text { Residents }\end{array}$} & \multicolumn{2}{c|}{$\begin{array}{c}\text { Local } \\
\text { Governm } \\
\text { ent }\end{array}$} & \multicolumn{2}{|c|}{$\begin{array}{c}\text { Grand } \\
\text { Mean }\end{array}$} & Rank \\
\cline { 2 - 10 } & WM & VI & WM & VI & WM & VI & WM & VI & \\
\hline $\begin{array}{l}\text { 1. The climate in the } \\
\text { tourist destination is } \\
\text { fine. }\end{array}$ & 3.43 & A & 3.68 & SA & 3.50 & SA & 3.54 & SA & 3 \\
\hline $\begin{array}{l}\text { 2. Tourist destinations } \\
\text { are surrounded by trees } \\
\text { and plants. }\end{array}$ & 3.43 & A & 3.84 & SA & 3.50 & SA & 3.59 & SA & 1 \\
\hline $\begin{array}{l}\text { 3. The cultural and } \\
\text { historical sites' } \\
\text { architecture is distinct }\end{array}$ & 3.26 & A & 3.62 & SA & 3.33 & A & 3.40 & A & 8 \\
\hline
\end{tabular}




\begin{tabular}{|c|c|c|c|c|c|c|c|c|c|}
\hline $\begin{array}{l}\text { and attractive from each } \\
\text { other. }\end{array}$ & & & & & & & & & \\
\hline $\begin{array}{l}\text { 4. Everything inside the } \\
\text { tourist destination is } \\
\text { well exhibited, } \\
\text { providing tourist } \\
\text { sufficient information in } \\
\text { order to gain } \\
\text { knowledge. }\end{array}$ & 3.22 & $\mathrm{~A}$ & 3.44 & $\mathrm{~A}$ & 3.00 & A & 3.22 & $\mathrm{~A}$ & 10 \\
\hline $\begin{array}{l}\text { 5. Tourist destinations } \\
\text { are free from noise } \\
\text { providing relaxing } \\
\text { ambiance for visitors. }\end{array}$ & 3.42 & $\mathrm{~A}$ & 3.52 & $\mathrm{SA}$ & 3.33 & $\mathrm{~A}$ & 3.42 & $\mathrm{~A}$ & 7 \\
\hline $\begin{array}{l}6 . \text { Tourist destinations } \\
\text { are clean and well } \\
\text { maintained. }\end{array}$ & 3.37 & $\mathrm{~A}$ & 3.52 & $\mathrm{SA}$ & 3.50 & $\mathrm{SA}$ & 3.46 & $\mathrm{~A}$ & 5.5 \\
\hline $\begin{array}{l}\text { 7. The local community } \\
\text { around the tourist } \\
\text { destinations are } \\
\text { hospitable and } \\
\text { welcoming. }\end{array}$ & 3.46 & $\mathrm{~A}$ & 3.70 & $\mathrm{SA}$ & 3.33 & $\mathrm{~A}$ & 3.50 & SA & 4 \\
\hline $\begin{array}{l}\text { 8. Tourist destinations } \\
\text { has complete facilities } \\
\text { and amenities for the } \\
\text { needs of the tourists. }\end{array}$ & 3.31 & $\mathrm{~A}$ & 3.30 & $\mathrm{~A}$ & 3.17 & $\mathrm{~A}$ & 3.26 & $\mathrm{~A}$ & 9 \\
\hline $\begin{array}{l}\text { 9. Tourist destinations } \\
\text { has scenic view and } \\
\text { natural attractions. }\end{array}$ & 3.41 & $\mathrm{~A}$ & 3.74 & $\mathrm{SA}$ & 3.50 & $\mathrm{SA}$ & 3.55 & SA & 2 \\
\hline $\begin{array}{l}\text { 10. Tourist destinations } \\
\text { has facilities for } \\
\text { reflections and } \\
\text { meditation. }\end{array}$ & 3.31 & $\mathrm{~A}$ & 3.56 & $\mathrm{SA}$ & 3.50 & $\mathrm{SA}$ & 3.46 & $\mathrm{~A}$ & 5.5 \\
\hline Composite Mean & 3.36 & $\mathrm{~A}$ & 3.59 & $\mathrm{SA}$ & 3.37 & $\mathrm{~A}$ & 3.44 & $\mathrm{~A}$ & \\
\hline
\end{tabular}

Legend: 3.50 - 4.00= Strongly Agree/ Highly Attractive; 2.50 - 3.49 = Agree/ Moderately Attractive; 1.50 - $2.49=$ Disagree/Less Attractive; $1.00-1.49=$ Strongly Disagree/ Not Attractive

In terms of the assessment of the respondents, they strongly agreed that tourist destinations are surrounded by trees and plants got the highest assessment with a weighted mean of 3.59. They also strongly agreed that tourist destinations have scenic view and natural attractions with a weighted mean of 3.54. Meanwhile, having everything inside the tourist destination is well exhibited got the lowest assessment with a weighted mean of 3.22 .

Results showed that having the tourist destinations surrounded by trees and plants will make CALABARZON region highly attractive particularly for those who are nature lover. Having this kind of environment, the region will attract tourists who are looking for places to relax and 
meditate by engaging themselves into nature tripping. Also, natural attractions are one good asset for the success of the tourism in the region.

Flora and fauna make a contribution mightily to most world economies related to tourism. For example, flora and fauna of Amazon appeal to numerous scientists and explorers. It's estimated that the Amazon rainforest contributes about $\$ 50$ million dollars to the Brazil economy. Exotic vacation places like the Caribbean, Bahamas, Panama, Indonesia and so on attract more travelers than any nation due to the extensive plant life and fauna. (What is Flora and Fauna? 2011)

Table 4 presents the assessment of the tourists, local residents and local government on the level of attractiveness of tourism industry in terms of price which attained a composite mean of 3.33 with a verbal interpretation of agree. This means that the level of attractiveness of tourism industry in CALABARZON is moderately attractive having competitive and affordable prices of tour packages and tourism related services which satisfy tourists that makes them to enjoy the place and travel back.

Table 4: Level of Attractiveness of Tourism Industry in terms of Price

\begin{tabular}{|l|l|l|l|l|l|l|l|l|l|}
\hline \multicolumn{1}{|c|}{ Price } & \multicolumn{2}{c}{ Tourists } & \multicolumn{2}{c|}{$\begin{array}{c}\text { Local } \\
\text { Residents }\end{array}$} & \multicolumn{2}{c|}{$\begin{array}{c}\text { Local } \\
\text { Government }\end{array}$} & \multicolumn{2}{c|}{$\begin{array}{c}\text { Grand } \\
\text { Mean }\end{array}$} & Rank \\
\cline { 2 - 10 } & WM & VI & WM & VI & WM & VI & & & \\
\hline $\begin{array}{l}\text { 1. Tour packages prices are } \\
\text { reasonable. }\end{array}$ & 3.24 & A & 3.20 & A & 3.50 & SA & 3.31 & A & 8 \\
\hline $\begin{array}{l}\text { 2. Accommodation rates } \\
\text { compliments with the facilities } \\
\text { and amenities offered. }\end{array}$ & 3.27 & A & 3.38 & A & 3.50 & SA & 3.38 & A & 2.5 \\
\hline $\begin{array}{l}\text { 3. Transportation fares to and } \\
\text { from tourist destinations are } \\
\text { enough and affordable. }\end{array}$ & 3.31 & A & 3.27 & A & 3.47 & A & 3.35 & A & 4.5 \\
\hline 4. Entrance fees are affordable. & 3.30 & A & 3.34 & A & 3.50 & SA & 3.38 & A & 2.5 \\
\hline $\begin{array}{l}\text { 5. Rental fees such as vans and } \\
\text { equipment usage are not high } \\
\text { and services provided is well } \\
\text { compensated. }\end{array}$ & 3.23 & A & 3.22 & A & 3.50 & SA & 3.32 & A & 6.5 \\
\hline $\begin{array}{l}\text { 6. Restaurants offers affordable } \\
\text { prices of food especially local } \\
\text { delicacies. }\end{array}$ & 3.22 & A & 3.22 & A & 3.17 & A & 3.20 & A & 10 \\
\hline $\begin{array}{l}\text { 7. Prices posted on websites are } \\
\text { the actual prices offered in the } \\
\text { tourist destinations. }\end{array}$ & 3.21 & A & 3.24 & A & 3.50 & SA & 3.32 & A & 6.6 \\
\hline $\begin{array}{l}\text { 8. The prices of tourist products } \\
\text { compliments with the actual } \\
\text { service given. }\end{array}$ & 3.24 & A & 3.30 & A & 3.50 & SA & 3.35 & A & 4.5 \\
\hline $\begin{array}{l}\text { 9. There are promos offered on } \\
\text { prices such as discounts and } \\
\text { freebies. }\end{array}$ & 3.20 & A & 3.24 & A & 3.33 & A & 3.26 & A & 9 \\
\hline
\end{tabular}




\begin{tabular}{|l|l|l|l|l|l|l|l|l|l|}
\hline $\begin{array}{l}\text { 10. Tour guides rates is enough } \\
\text { to the given services. }\end{array}$ & 3.29 & A & 3.50 & SA & 3.50 & SA & 3.43 & A & 1 \\
\hline Composite Mean & 3.25 & A & 3.29 & S & 3.44 & A & 3.33 & A & \\
\hline
\end{tabular}

Legend: $3.50-4.00=$ Strongly Agree/ Highly Attractive; $2.50-3.49=$ Agree/ Moderately Attractive; 1.50 - $2.49=$ Disagree/Less Attractive; $1.00-1.49=$ Strongly Disagree/ Not Attractive

In the assessment of the respondents, they agreed that tour guides rates are enough to the given services got the highest assessment with a weighted mean of 3.43. They also agreed that the rates of the accommodation compliments with the offered facilities and amenities and affordable entrance fees with a weighted mean of 3.38 respectively. Meanwhile, affordable prices of food and delicacies to restaurants got the lowest assessment with a weighted mean of 3.20.

This is a manifestation that appropriate tour guide rates make CALABARZON region moderately attractive for having a very good tour guide that are not collecting too much fee is also an advantage in the tourism industry. Of course, this will create loyal customers and good tour guides will lead to satisfaction of the tourists. Good tour guide rates will also increase the support of tourists in terms of loyalty for it will also create good impression which is an important factor of customer satisfaction.

According Heung, Zhang and Jiang (2015) it is essential that tour guides prioritize tourists' desires and hobbies first in offering superior fee of services and enhancement of the typical tourist experience. Critical tour leadership and administration skills, therefore, include the ability to arrange and deal with traveler groups, coordination of affiliated vendors and suppliers of items and services, time management, scheduling and logistics, and day-to-day trouble solving. Tourist companies generally incorporate a diverse range of humans from many walks of lifestyles and different backgrounds, accordingly interpersonal skills and the capacity for appreciation cultural differences are paramount.

Table 5 presents the assessment of the tourists, local residents and local government on the level of attractiveness of tourism industry in terms of destination image which attained a composite mean of 3.30 with a verbal interpretation of agree. This means that the level of attractiveness of tourism industry in CALABARZON is moderately attractive for tourists and local government and highly attractive for the local residents having displayed a good image of the different destination that are well preserved and conserved which is a good factor in attracting tourists in the place.

Table 5: Level of Attractiveness of Tourism Industry in terms of Destination Image

\begin{tabular}{|l|l|l|l|l|l|l|l|l|l|l|}
\hline \multicolumn{1}{|c|}{ Destination Image } & \multicolumn{2}{c|}{ Tourists } & \multicolumn{2}{c|}{$\begin{array}{c}\text { Local } \\
\text { Residents }\end{array}$} & \multicolumn{2}{c|}{$\begin{array}{c}\text { Local } \\
\text { Government }\end{array}$} & \multicolumn{2}{c|}{$\begin{array}{c}\text { Grand } \\
\text { Mean }\end{array}$} & Rank \\
\cline { 2 - 10 } & WM & VI & WM & VI & WM & VI & WM & VI & \\
\hline $\begin{array}{l}\text { 1. Tourist destinations depicts } \\
\text { rich culture of the place. }\end{array}$ & 3.35 & A & 3.72 & SA & 3.50 & SA & 3.52 & SA & 1 \\
\hline $\begin{array}{l}\text { 2. Tourist destinations are } \\
\text { spacious for the tourists to } \\
\text { easily roam around. }\end{array}$ & 3.36 & A & 3.68 & SA & 3.50 & SA & 3.51 & SA & 2 \\
\hline $\begin{array}{l}\text { 3. Accommodation } \\
\text { establishments are well- }\end{array}$ & 3.37 & A & 3.42 & A & 3.67 & SA & 3.49 & A & 3 \\
\hline
\end{tabular}




\begin{tabular}{|l|l|l|l|l|l|l|l|l|l|}
\hline $\begin{array}{l}\text { maintained and has a good } \\
\text { ambiance. }\end{array}$ & & & & & & & & & \\
\hline $\begin{array}{l}\text { 4. Roads and bridges going to } \\
\text { and from the different tourist } \\
\text { destinations are firm and in- } \\
\text { tact. }\end{array}$ & 3.11 & $\mathrm{~A}$ & 3.12 & $\mathrm{~A}$ & 3.33 & $\mathrm{~A}$ & 3.19 & $\mathrm{~A}$ & 10 \\
\hline $\begin{array}{l}\text { 5. Adobe rocks and } \\
\text { foundation of historical } \\
\text { churches stand still and free } \\
\text { from danger. }\end{array}$ & 3.24 & $\mathrm{~A}$ & 3.50 & $\mathrm{SA}$ & 3.17 & $\mathrm{~A}$ & 3.30 & $\mathrm{~A}$ & 8 \\
\hline $\begin{array}{l}\text { 6. Historical houses are well- } \\
\text { maintained and preserved. }\end{array}$ & 3.15 & $\mathrm{~A}$ & 3.32 & $\mathrm{~A}$ & 3.33 & $\mathrm{~A}$ & 3.27 & $\mathrm{~A}$ & 9 \\
\hline $\begin{array}{l}\text { 7. Natural attractions depicts } \\
\text { healthy environment with } \\
\text { vibrant colors from plants and } \\
\text { trees. }\end{array}$ & 3.33 & $\mathrm{~A}$ & 3.64 & $\mathrm{SA}$ & 3.33 & $\mathrm{~A}$ & 3.43 & $\mathrm{~A}$ & 4.5 \\
\hline $\begin{array}{l}\text { 8. Water from the rivers and } \\
\text { lakes are clear and clean and } \\
\text { good fro swimming. }\end{array}$ & 3.28 & $\mathrm{~A}$ & 3.52 & $\mathrm{SA}$ & 3.33 & $\mathrm{~A}$ & 3.37 & $\mathrm{~A}$ & 6 \\
\hline $\begin{array}{l}\text { 9. Tourist destinations are } \\
\text { well-maintained and properly } \\
\text { managed. }\end{array}$ & 3.17 & $\mathrm{~A}$ & 3.56 & $\mathrm{SA}$ & 3.35 & $\mathrm{~A}$ & 3.36 & $\mathrm{~A}$ & 7 \\
\hline $\begin{array}{l}\text { 10. Tourist destinations } \\
\text { clearly depicts the historical } \\
\text { background of the place. }\end{array}$ & 3.26 & $\mathrm{~A}$ & 3.52 & $\mathrm{SA}$ & 3.50 & $\mathrm{SA}$ & 3.43 & $\mathrm{~A}$ & 4.5 \\
\hline Composite Mean & 3.26 & $\mathrm{~A}$ & 3.50 & $\mathrm{SA}$ & 3.40 & $\mathrm{~A}$ & 3.39 & $\mathrm{~A}$ & \\
\hline
\end{tabular}

Legend: 3.50 - 4.00= Strongly Agree/ Highly Attractive; 2.50 - 3.49 = Agree/ Moderately Attractive; 1.50 - 2.49 =Disagree/Less Attractive; 1.00 - $1.49=$ Strongly Disagree/ Not Attractive

In terms of the assessment of the respondents, they strongly agreed that tourist destinations depict rich culture of the place got the highest assessment with a weighted mean of 3.52. They also strongly agreed that tourist destinations are spacious for the tourists to easily roam around with a weighted mean of 3.51. Meanwhile, roads and bridges going to and from the different tourist destinations are firm and in-tact got the lowest assessment with a weighted mean of 3.19.

This indicates that the culture itself of the CALABARZON region, make the place highly attractive to tourists particularly to those who want to learn the rich culture of the region. Also, culture is one of the factor that attracts tourists to visit a certain place because of the discoveries and knowledge that will be imparted to them.

There is no denying the truth that culture and heritage tourism tends to appeal to high-yield tourists. While global figures can be hard to obtain, all reachable statistics on tourism in various individual markets like the UK, New Zealand, Australia, India, and etc. reveal a regular pattern. Culture and heritage tourists regularly continue to be longer and spend a lot greater money in ordinary than different travelers do. In fact, one find out about confirmed that a way of life and heritage visitor 
spent as lots as $38 \%$ greater per day and they stayed $22 \%$ longer overall in contrast to different types of travelers. (Childs, 2018)

Table 6 presents the assessment of the tourists, local residents and local government on the level of attractiveness of tourism industry in terms of risk and reward which attained a composite mean of 3.39 with a verbal interpretation of agree. This means that the level of attractiveness of tourism industry in CALABARZON is moderately attractive having provided the safety and security needed by the tourists as well as having complete facilities and well trained staff to attend with their needs.

Table 6: Level of Attractiveness of Tourism Industry in terms of Risk and Reward

\begin{tabular}{|c|c|c|c|c|c|c|c|c|c|}
\hline \multirow[t]{2}{*}{ Risk and Reward } & \multicolumn{2}{|c|}{ Tourists } & \multicolumn{2}{|c|}{$\begin{array}{c}\text { Local } \\
\text { Residents }\end{array}$} & \multicolumn{2}{|c|}{$\begin{array}{c}\text { Local } \\
\text { Government }\end{array}$} & \multicolumn{2}{|c|}{$\begin{array}{l}\text { Grand } \\
\text { Mean }\end{array}$} & \multirow[t]{2}{*}{ Rank } \\
\hline & WM & VI & WM & VI & WM & VI & WM & VI & \\
\hline $\begin{array}{l}\text { 1. Each tourist destination } \\
\text { provides safety equipment in } \\
\text { case of natural disaster such as } \\
\text { fires, earthquakes and } \\
\text { typhoons. }\end{array}$ & 3.22 & $\mathrm{~A}$ & 3.54 & SA & 3.00 & $\mathrm{~A}$ & 3.25 & $\mathrm{~A}$ & 10 \\
\hline $\begin{array}{l}\text { 2. Security guards and } \\
\text { barangay officials are roaming } \\
\text { nearby tourist destinations for } \\
\text { 24-hours. }\end{array}$ & 3.17 & A & 3.46 & A & 3.17 & A & 3.27 & A & 9 \\
\hline $\begin{array}{l}\text { 3. The community or people } \\
\text { living in the tourist destination } \\
\text { are friendly. }\end{array}$ & 3.36 & A & 3.70 & $\mathrm{SA}$ & 3.50 & SA & 3.52 & SA & 2 \\
\hline $\begin{array}{l}\text { 4. Services offered by tourism } \\
\text { establishments are satisfactory } \\
\text { to meet tourist expectations. }\end{array}$ & 3.29 & A & 3.39 & A & 3.50 & $\mathrm{SA}$ & 3.39 & A & 4 \\
\hline $\begin{array}{l}\text { 5. Accommodation } \\
\text { establishments are well } \\
\text { constructed with complete } \\
\text { facilities and amenities. }\end{array}$ & 3.25 & A & 3.22 & A & 3.50 & SA & 3.32 & A & 6.5 \\
\hline $\begin{array}{l}\text { 6. Tourism establishment staff } \\
\text { are friendly and attentive. }\end{array}$ & 3.36 & A & 3.70 & $\mathrm{SA}$ & 4.00 & $\mathrm{SA}$ & 3.68 & SA & 1 \\
\hline $\begin{array}{l}\text { 7. Tourist destinations are } \\
\text { frequently visited by number } \\
\text { of tourists. }\end{array}$ & 3.31 & $\mathrm{~A}$ & 3.50 & $\mathrm{SA}$ & 3.50 & SA & 3.44 & $\mathrm{~A}$ & 3 \\
\hline $\begin{array}{l}\text { 8. Group tours and field trips } \\
\text { are always visiting different } \\
\text { tourist destinations. }\end{array}$ & 3.24 & A & 3.48 & A & 3.33 & A & 3.35 & A & 5 \\
\hline $\begin{array}{l}\text { 9. Services offered has } \\
\text { alternative offers in case of } \\
\text { failure of service. }\end{array}$ & 3.26 & A & 3.38 & A & 3.33 & A & 3.32 & A & 6.5 \\
\hline
\end{tabular}




\begin{tabular}{|l|l|l|l|l|l|l|l|l|l|}
\hline $\begin{array}{l}\text { 10. There are additional } \\
\text { freebies and discounts offered } \\
\text { by tourist establishments. }\end{array}$ & 3.21 & A & 3.36 & A & 3.33 & A & 3.30 & A & 8 \\
\hline Composite Mean & 3.27 & A & 3.47 & A & 3.43 & A & 3.39 & A & \\
\hline
\end{tabular}

Legend: $3.50-4.00=$ Strongly Agree/ Highly Attractive; $2.50-3.49=$ Agree/ Moderately Attractive; 1.50 - $2.49=$ Disagree/Less Attractive; $1.00-1.49=$ Strongly Disagree/ Not Attractive

In terms of the assessment of the respondents, they strongly agreed that tourism establishment staff are friendly and attentive got the highest assessment with a weighted mean of 3.68. They also strongly agreed that the community or people living in the tourist destination are friendly with a weighted mean of 3.52. Meanwhile, each tourist destinations provides equipment for disasters got the lowest assessment with a weighted mean of 3.17.

Results manifests that having a friendly and attentive staff will make the CALABARZON region highly attractive for having this kind of attitude is a plus factor and will create a good impression to the tourists that will lead to their satisfaction. Also, having been with a staff with this kind of attitude that is well trained by the local government will also lead to success in attracting tourists in the region.

The operation of resort groups is relatively service-orientated. This high service orientation is due to the inseparable nature of services in which these services are produced and consumed at the identical time. Guests are section of a service production. The close encounter of an worker and a guest plays a giant function in the ultimate decision-making of that guest's inferences on whether to come back to that specific hotel or not. Therefore, the employees' function can lead to the success or failure of the motel business. In order for motel corporations to be successful, they want to have employees who are well-trained, well-informed and motivated, with the critical sources at their disposal (Kusluvan, Ilhan \& Buyruk, 2015).

Table 7 presents the assessment of the tourists, local residents and local government on the level of attractiveness of tourism industry in terms of geographical proximity which attained a composite mean of 3.26 with a verbal interpretation of agree. This means that the level of attractiveness of tourism industry in CALABARZON is moderately attractive having provided an accessible tourist destination which creates a good impression to tourists in visiting the place.

Table 7: Level of Attractiveness of Tourism Industry in terms of Geographical Proximity

\begin{tabular}{|l|l|l|l|l|l|l|l|l|l|}
\hline \multicolumn{1}{|c|}{ Geographical Proximity } & \multicolumn{2}{|c|}{ Tourists } & \multicolumn{2}{c|}{$\begin{array}{c}\text { Local } \\
\text { Residents }\end{array}$} & \multicolumn{2}{c|}{$\begin{array}{c}\text { Local } \\
\text { Government }\end{array}$} & \multicolumn{2}{c|}{$\begin{array}{c}\text { Grand } \\
\text { Mean }\end{array}$} & Rank \\
\cline { 2 - 10 } & WM & VI & WM & VI & WM & VI & WM & VI & \\
\hline $\begin{array}{l}\text { 1. Road signage are present } \\
\text { and can be easily seen by } \\
\text { tourist. }\end{array}$ & 3.23 & A & 3.58 & SA & 3.50 & SA & 3.44 & A & 1 \\
\hline $\begin{array}{l}\text { 2. Full information about the } \\
\text { facilities, terminal location and } \\
\text { local transportation are made } \\
\text { available to all passenger and } \\
\text { tourists. }\end{array}$ & 3.19 & A & 3.58 & SA & 3.33 & A & 3.37 & A & 3 \\
\hline
\end{tabular}




\begin{tabular}{|l|l|l|l|l|l|l|l|l|l|}
\hline $\begin{array}{l}\text { 3. Tourist destinations uses } \\
\text { different transportation such as } \\
\text { tricycle, jeep and boat. }\end{array}$ & 3.23 & $\mathrm{~A}$ & 3.54 & $\mathrm{SA}$ & 3.50 & $\mathrm{SA}$ & 3.42 & $\mathrm{~A}$ & 2 \\
\hline $\begin{array}{l}\text { 4. There are regular trip going } \\
\text { to and from the different } \\
\text { destinations that is 24-hour } \\
\text { available to the public. }\end{array}$ & 2.92 & $\mathrm{SA}$ & 3.32 & $\mathrm{~A}$ & 3.00 & $\mathrm{~A}$ & 3.08 & $\mathrm{~A}$ & 9.5 \\
\hline $\begin{array}{l}\text { 5. Jeepney, tricycle and boat } \\
\text { fares are at reasonable prices. }\end{array}$ & 3.06 & $\mathrm{~A}$ & 3.52 & $\mathrm{SA}$ & 3.33 & $\mathrm{~A}$ & 3.30 & $\mathrm{~A}$ & 4 \\
\hline $\begin{array}{l}\text { 6. The transportation to-and- } \\
\text { from the tourist destinations is } \\
\text { far from the city. }\end{array}$ & 3.08 & $\mathrm{~A}$ & 3.34 & $\mathrm{~A}$ & 2.83 & $\mathrm{~A}$ & 3.08 & $\mathrm{~A}$ & 9.5 \\
\hline $\begin{array}{l}\text { 7. Complete information fares, } \\
\text { schedules and route of local } \\
\text { transportation is provided. }\end{array}$ & 3.11 & $\mathrm{~A}$ & 3.46 & $\mathrm{~A}$ & 3.17 & $\mathrm{~A}$ & 3.25 & $\mathrm{~A}$ & 6 \\
\hline $\begin{array}{l}\text { 8. Boundary markers are } \\
\text { constructed/ installed. }\end{array}$ & 3.17 & $\mathrm{~A}$ & 3.36 & $\mathrm{~A}$ & 3.33 & $\mathrm{~A}$ & 3.29 & $\mathrm{~A}$ & 5 \\
\hline $\begin{array}{l}\text { 9. The road to and from the } \\
\text { different tourist destinations is } \\
\text { firmly constructed with } \\
\text { cement. }\end{array}$ & 3.09 & $\mathrm{~A}$ & 3.14 & $\mathrm{~A}$ & 3.33 & $\mathrm{~A}$ & 3.19 & $\mathrm{~A}$ & 8 \\
\hline $\begin{array}{l}\text { 10. Road to and from the } \\
\text { different tourist destinations is } \\
\text { accessible to all types of } \\
\text { vehicles. }\end{array}$ & 3.11 & $\mathrm{~A}$ & 3.16 & $\mathrm{~A}$ & 3.33 & $\mathrm{~A}$ & 3.20 & $\mathrm{~A}$ & 7 \\
\hline Composite Mean & 3.12 & $\mathrm{~A}$ & 3.40 & $\mathrm{~A}$ & 3.27 & $\mathrm{~A}$ & 3.26 & $\mathrm{~A}$ & \\
\hline
\end{tabular}

Legend: $3.50-4.00=$ Strongly Agree/ Highly Attractive; $2.50-3.49=$ Agree/ Moderately Attractive; 1.50 - $2.49=$ Disagree/Less Attractive; $1.00-1.49=$ Strongly Disagree/ Not Attractive

In terms of the assessment of the respondents, they agreed that road signage is present and can be easily seen by tourist got the highest assessment with a weighted mean of 3.44. They also agreed that tourist destinations use different transportation with a weighted mean of 3.42. Meanwhile, there are regular trip going to and from the different destinations and transportation to and from the destination are far from the city got the lowest assessment with a weighted mean of 3.08 respectively.

This is a manifestation that having clearly visible road signage will make CALABARZON region moderately attractive because this will help the tourists to easily locate the different tourist destinations in the region which will give comfort to them. Having an easily located destinations will also increase the potential to the market to be discovered and recognized by the different stakeholders for the information needed will be widespread to the public which can catch their attention and will increase the opportunity to be visited.

Compared to the other subjects within the tourism field, visitor symptoms are one of the subjects which have now not but studied commonly. Despite the quantity of research performed on this subject, traveller signs are one of the requisite factors for visitor destinations to be hospitable 
vacation spot for tourists. Visitors are regularly pretty dependent on the signs and symptoms inside new destination, e.g. to discover a way, to confirm that one is moving towards the proper direction. Without the signs and symptoms traffic can also feel insecure and frustrated, as it could be challenging for them to locate the proper way or even to comprehend where they are standing. In order to be a visitor pleasant and without difficulty accessible destination where visitors can go comfortably, splendid sign establishment will become necessary. (KankochiikidukuriAnnaihyoshikikenkyukai 2015).

Table 8 presents the summary of assessment of the tourists, local residents and local government on the level of attractiveness of tourism industry in CALABARZON which attained a composite mean of 3.25, 3.46 and 3.38 with a verbal interpretation of agree respectively. This means that CALABARZON region is moderately attractive to tourists having the existence of different tourism related establishments that provide good services and competitive tourist destinations that can be compared to other region in the country.

Table 8: Summary Table on the Level of Attractiveness of Tourism Industry in CALABARZON

\begin{tabular}{|l|l|l|l|l|l|l|}
\hline \multirow{2}{*}{ Indicators } & \multicolumn{2}{|c|}{ Tourists } & \multicolumn{2}{c|}{ Local Residents } & \multicolumn{2}{c|}{ Local Government } \\
\cline { 2 - 7 } & WM & VI & \multicolumn{1}{c|}{ WM } & \multicolumn{1}{c|}{ VI } & WM & VI \\
\hline 1. Cultural Proximity & 3.25 & $\mathrm{~A}$ & 3.50 & SA & 3.35 & $\mathrm{~A}$ \\
\hline 2. Destination Environment & 3.36 & $\mathrm{~A}$ & 3.59 & $\mathrm{SA}$ & 3.37 & $\mathrm{~A}$ \\
\hline 3. Price & 3.25 & $\mathrm{~A}$ & 3.29 & $\mathrm{~S}$ & 3.44 & $\mathrm{~A}$ \\
\hline 4. Destination Image & 3.26 & $\mathrm{~A}$ & 3.50 & $\mathrm{SA}$ & 3.40 & $\mathrm{~A}$ \\
\hline 5. Risk and Reward & 3.27 & $\mathrm{~A}$ & 3.47 & $\mathrm{~A}$ & 3.43 & $\mathrm{~A}$ \\
\hline 6. Geographical Proximity & 3.12 & $\mathrm{~A}$ & 3.40 & $\mathrm{~A}$ & 3.27 & $\mathrm{~A}$ \\
\hline Composite Mean & 3.25 & $\mathrm{~A}$ & 3.46 & $\mathrm{~A}$ & 3.38 & $\mathrm{~A}$ \\
\hline
\end{tabular}

Legend: 3.50 - 4.00= Strongly Agree/ Highly Attractive; 2.50 - 3.49= Agree/ Moderately Attractive; 1.50 - 2.49 =Disagree/Less Attractive; 1.00 - $1.49=$ Strongly Disagree/ Not Attractive

It can also be gleaned from the table the destination environment is the factor that makes CALABARZON region moderately attractive in the assessment of the tourists with a weighted mean of 3.36 and a verbal interpretation of agree and highly attractive in the assessment of the local residents with a weighted mean of 3.59 and a verbal interpretation of strongly agree. In terms of the assessment of the local residents, price makes the CALABARZON moderately attractive with a weighted mean of 3.44 and a verbal interpretation of agree.

This means that destination environment and price are key factors that attract tourists in the region. Good physical features and appearance of destinations and affordable prices of tourist services create a good impression to the tourists for them to experience what CALABARZON can offer and how beautiful the region is.

Tourism concept has diagnosed the necessary significance of environmental high-quality for ensuring the future existence of most sorts of traveler destinations. Tourism managers have been inclined to incorporate environmental measures into present day administration techniques and methods if they resulted in lower expenses and/or greater revenues and profits (Stabler \& Goodal, 2017). Increasing environmental consciousness, traveler demand for better high-quality and the improved competition among locations have modified the situation; environmental pleasant has 
turn out to be a cutting-edge issue. Environmental first-class of a vacation spot is a prevailing trouble in making journey associated decision; it is a competitiveness aspect among specific traveler locations with various environmental quality. In many cases, environmental targets and practice must be included into the modern-day attitudes, management strategies and techniques in order to remain aggressive on the traveler market, e.g. in order to forestall a minimize in sales and prices, revenues and profits.

For the third objective, the researcher used of multiple regression analysis in which they used economic model to describe the effect of quality of investment on the attractiveness of tourism industry in CALABARZON.

Multiple regression analysis is used to examine the relationship between one mathematical variable and a set of other variables. In addition, multiple regression analysis is used to examine the correlation between two variables after controlling another covariate.

Table 9: Effect of Investment Climate on the Attractiveness of Tourism Industry in CALABARZON in terms of Cultural Proximity

\begin{tabular}{|l|l|l|l|c|l|l|}
\hline \multirow{1}{*}{ Variables } & \multicolumn{2}{|c|}{$\begin{array}{c}\text { Unstandardized } \\
\text { Coefficients }\end{array}$} & \multirow{2}{*}{$\begin{array}{c}\text { Standardized } \\
\text { Coefficients Beta }\end{array}$} & $\mathbf{t}$ & Sig. & $\begin{array}{c}\text { Verbal } \\
\text { Interpretation }\end{array}$ \\
\cline { 2 - 3 } & B & Std Error & & & & \\
\hline 1 (Constant) & .894 & .121 & & 3.377 & .000 & Significant \\
\hline $\begin{array}{l}\text { Macro- } \\
\text { Fundamental }\end{array}$ & .138 & .043 & .149 & & .001 & Significant \\
\hline Governance & .291 & .043 & .326 & 6.840 & .000 & Significant \\
\hline Infrastructure & .321 & .047 & .349 & 6.758 & .000 & Significant \\
\hline
\end{tabular}

R-Squared $\quad .512$

F-stat $\quad 135.113$

Prob(F-stat) $\quad .000$

Table 9 showed the summary of multiple regression results for the effects of quality of investment in terms of macro-fundamental, governance and infrastructure. Having probability value of fstatistics is .000 the whole econometric model is reflected as significant. The value of r-square which is .512 indicates that 51.20 percent of the variation of attractiveness of tourism industry in CALABARZON can be explained by the changes in the quality of investment. The value of $y-$ intercept .894 holding other variables constant. This means that .894 percent will be increased in attractiveness value if the quality of investment are equal to zero. The coefficient of macrofundamental, governance and infrastructure are all positive which implies that an increase in the quality of investment will promote attractiveness of tourism industry in terms of cultural proximity.

Culture and tourism have a mutually beneficial relationship which can strengthen the attractiveness and competitiveness of regions and countries. Culture is an increasing number of an essential element of the tourism product, which also creates area of expertise in a crowded global marketplace. At the same time, tourism affords an vital capability of improving way of life and creating earnings which can guide and beef up cultural heritage, cultural production and creativity. Creating a robust relationship between tourism and culture can therefore assist destinations to turn 
out to be extra pleasing and competitive as areas to live, visit, work and invest in. (The Impact of Culture on Tourism, 2012)

Table 10: Effect of Investment Climate on the Attractiveness of Tourism Industry in CALABARZON in terms of Destination Environment

\begin{tabular}{|l|l|l|l|l|l|l|}
\hline \multicolumn{1}{|c|}{ Variables } & \multicolumn{2}{|c|}{$\begin{array}{c}\text { Unstandardized } \\
\text { Coefficients }\end{array}$} & $\begin{array}{c}\text { Standardized } \\
\text { Coefficients Beta }\end{array}$ & $\mathbf{t}$ & Sig. & \multicolumn{1}{|c|}{$\begin{array}{c}\text { Verbal } \\
\text { Interpretation }\end{array}$} \\
\cline { 2 - 6 } & $\mathbf{B}$ & Std Error & & 12.738 & .000 & Significant \\
\hline 1 (Constant) & 1.572 & .123 & & 2.704 & .007 & Significant \\
\hline $\begin{array}{l}\text { Macro- } \\
\text { Fundamental }\end{array}$ & .119 & .044 & .143 & 5.025 & .000 & Significant \\
\hline Governance & .218 & .043 & .272 & 4.876 & .000 & Significant \\
\hline Infrastructure & .236 & .048 & .287 & & & \\
\hline
\end{tabular}

R-Squared $\quad .369$

F-stat $\quad 75.184$

Prob(F-stat) $\quad .000$

Table 10 showed the summary of multiple regression results for the effects of quality of investment in terms of macro-fundamental, governance and infrastructure. Having probability value of fstatistics is .000 the whole econometric model is reflected as significant. The value of r-square which is .369 indicates that 36.90 percent of the variation of attractiveness of tourism industry in CALABARZON can be explained by the changes in the quality of investment. The value of $y-$ intercept 1.572 holding other variables constant. This means that 1.572 percent will be increased in attractiveness value if the quality of investment are equal to zero. The coefficient of macrofundamental, governance and infrastructure are all positive which implies that an increase in the quality of investment will promote attractiveness of tourism industry in terms of destination environment.

Developing nations especially benefit from the tourism industry's superb economic, environmental, and social impacts, thru the advent of jobs, renovation and occasion of indigenous culture, discount of poverty, and promotion of environmental conservation (environmentallyfriendly alternative livelihoods). In Tanzania, for example, "gross tourism receipts accounted for much less than $10 \%$ of total export profits in the 1980s. By 2000, tourism used to be the top export earner, above coffee and cotton, and now bills for over $35 \%$ of whole items and offerings exports" (UNCTAD, 2010).

Table 11: Effect of Investment Climate on the Attractiveness of Tourism Industry in CALABARZON in terms of Price

\begin{tabular}{|l|l|l|l|l|l|l|}
\hline \multirow{2}{*}{ Variables } & \multicolumn{2}{|c|}{$\begin{array}{c}\text { Unstandardized } \\
\text { Coefficients }\end{array}$} & $\begin{array}{c}\text { Standardized } \\
\text { Coefficients Beta }\end{array}$ & $\mathbf{t}$ & Sig. & \multicolumn{1}{c|}{$\begin{array}{c}\text { Verbal } \\
\text { Interpretation }\end{array}$} \\
\cline { 2 - 7 } & $\mathbf{B}$ & Std Error & & & & \\
\hline 1 (Constant) & 1.134 & .142 & & 7.956 & .000 & Significant \\
\hline $\begin{array}{l}\text { Macro- } \\
\text { Fundamental }\end{array}$ & .126 & .051 & .131 & 2.493 & .013 & Significant \\
\hline Governance & .221 & .050 & .237 & 4.411 & .000 & Significant \\
\hline Infrastructure & .321 & .056 & .336 & 5.747 & .000 & Significant \\
\hline
\end{tabular}




$\begin{array}{ll}\text { R-Squared } & .376 \\ \text { F-stat } & 77.641 \\ \text { Prob(F-stat) } & .000\end{array}$

Table 11 showed the summary of multiple regression results for the effects of quality of investment in terms of macro-fundamental, governance and infrastructure. Having probability value of fstatistics is .000 the whole econometric model is reflected as significant. The value of r-square which is .376 indicates that 37.60 percent of the variation of attractiveness of tourism industry in CALABARZON can be explained by the changes in the quality of investment. The value of $y-$ intercept 1.134 holding other variables constant. This means that 1.134 percent will be increased in attractiveness value if the quality of investment are equal to zero. The coefficient of macrofundamental, governance and infrastructure are all positive which implies that an increase in the quality of investment will promote attractiveness of tourism industry in terms of price.

Investment is a spending to capital and economic belongings that are made by way of private or public agencies or governments in the expectation of getting future returns. Tourism investments are centered to tourism industry, and such investments underlie and guide tourism development. Investment selections refer to capital budgeting selections as selections to accumulate assets. Investment process describes how funding initiatives are being carried out in companies and organizations. (Dwyer et al. 2010.)

Table 12 showed the summary of multiple regression results for the effects of quality of investment in terms of macro-fundamental, governance and infrastructure. Having probability value of $\mathrm{f}$ statistics is .000 the whole econometric model is reflected as significant. The value of $r$-square which is .346 indicates that 34.60 percent of the variation of attractiveness of tourism industry in CALABARZON can be explained by the changes in the quality of investment. The value of $y-$ intercept 1.647 holding other variables constant. This means that 1.647 percent will be increased in attractiveness value if the quality of investment are equal to zero. The coefficient of macrofundamental, governance and infrastructure are all positive which implies that an increase in the quality of investment will promote attractiveness of tourism industry in terms of destination image.

Table 12: Effect of Investment Climate on the Attractiveness of Tourism Industry in CALABARZON in terms of Destination Image

\begin{tabular}{|l|l|l|l|l|l|l|}
\hline \multirow{2}{*}{ Variables } & \multicolumn{2}{|c|}{$\begin{array}{c}\text { Unstandardized } \\
\text { Coefficients }\end{array}$} & $\begin{array}{c}\text { Standardized } \\
\text { Coefficients Beta }\end{array}$ & $\mathbf{t}$ & Sig. & $\begin{array}{c}\text { Verbal } \\
\text { Interpretation }\end{array}$ \\
\cline { 2 - 6 } & $\mathbf{B}$ & Std Error & & & & \\
\hline 1 (Constant) & 1.647 & .120 & & 13.738 & .000 & Significant \\
\hline $\begin{array}{l}\text { Macro- } \\
\text { Fundamental }\end{array}$ & .079 & .043 & .099 & & .065 & Not Significant \\
\hline Governance & .166 & .042 & .217 & 3.937 & .000 & Significant \\
\hline Infrastructure & .276 & .047 & .352 & 5.885 & .000 & Significant \\
\hline
\end{tabular}

R-Squared $\quad .346$

F-stat $\quad 68.012$

Prob(F-stat) $\quad .000$

Geographical characteristics constitute the basic stipulations of a tourism vacation spot aspiring to strengthen in tourism market and turn it into a international traveller attraction. Geographical 
location can help and ease improvement and development of a tourism destination with the blessings providing competitiveness towards other destinations. The characteristics of a tourism middle generally have an effect on vacationer expectations and excursion conceptualization. Matching the geographical features of an area with the right tourism type, it can hastily advance the place as a global traveller destination. As section of geography the distance and accessibility are also important factors shaping the fee shape and traveller preferences in tourism. (Akdag and Oter, 2011)

Table 13: Effect of Investment Climate on the Attractiveness of Tourism Industry in CALABARZON in terms of Risk and Reward

\begin{tabular}{|l|l|l|l|l|l|l|}
\hline \multirow{1}{*}{ Variables } & \multicolumn{2}{|c|}{$\begin{array}{c}\text { Unstandardized } \\
\text { Coefficients }\end{array}$} & $\begin{array}{c}\text { Standardized } \\
\text { Coefficients Beta }\end{array}$ & $\mathbf{t}$ & Sig. & \multicolumn{1}{c|}{$\begin{array}{c}\text { Verbal } \\
\text { Interpretation }\end{array}$} \\
\cline { 2 - 6 } & $\mathbf{B}$ & Std Error & & & & \\
\hline 1 (Constant) & 1.273 & .126 & & 2.090 & .000 & Significant \\
\hline $\begin{array}{l}\text { Macro- } \\
\text { Fundamental }\end{array}$ & .094 & .045 & .106 & 5.347 & .000 & Significant \\
\hline Governance & .238 & .044 & .280 & 6.104 & .000 & Significant \\
\hline Infrastructure & .302 & .050 & .346 & & & \\
\hline
\end{tabular}

R-Squared $\quad .412$

F-stat $\quad 90.018$

Prob(F-stat) $\quad .000$

Table 13 showed the summary of multiple regression results for the effects of quality of investment in terms of macro-fundamental, governance and infrastructure. Having probability value of fstatistics is .000 the whole econometric model is reflected as significant. The value of r-square which is .412 indicates that 41.20 percent of the variation of attractiveness of tourism industry in CALABARZON can be explained by the changes in the quality of investment. The value of $y-$ intercept 1.273 holding other variables constant. This means that 1.273 percent will be increased in attractiveness value if the quality of investment are equal to zero. The coefficient of macrofundamental, governance and infrastructure are all positive which implies that an increase in the quality of investment will promote attractiveness of tourism industry in terms of risk and reward. Understanding us of a competitiveness in tourism is a important consideration for policy makers and a fundamental task for experts in supplying proof to inform decision making. Various indications have been developed through exclusive agencies over the years to tackle unique elements of competitiveness however there has remained a lack of an ordinary measurement framework for competitiveness in tourism for the use of governments. The contemporary work by using member and accomplice countries seeks to address this hole and make a high-quality contribution to the sensible measurement of competitiveness. (Dupeyras and MacCallum, 2013) 
Table 14: Effect of Investment Climate on the Attractiveness of Tourism Industry in CALABARZON in terms of Geographical Proximity

\begin{tabular}{|l|c|c|l|c|l|l|}
\hline \multirow{1}{*}{ Variables } & \multicolumn{2}{|c|}{$\begin{array}{c}\text { Unstandardized } \\
\text { Coefficients }\end{array}$} & \multirow{2}{*}{$\begin{array}{c}\text { Standardized } \\
\text { Coefficients Beta }\end{array}$} & t & Sig. & $\begin{array}{c}\text { Verbal } \\
\text { Interpretation }\end{array}$ \\
\cline { 2 - 5 } & $\mathbf{B}$ & \multicolumn{1}{|c|}{ Std Error } & & & & \\
\hline 1 (Constant) & .571 & .141 & & 4.044 & .000 & Significant \\
\hline $\begin{array}{l}\text { Macro- } \\
\text { Fundamental }\end{array}$ & .151 & .050 & .144 & 2.999 & .003 & Significant \\
\hline Governance & .278 & .050 & .277 & 5.608 & .000 & Significant \\
\hline Infrastructure & .384 & .055 & .372 & 6.941 & .000 & Significant \\
\hline
\end{tabular}

R-Squared $\quad .476$

F-stat $\quad 117.082$

$\operatorname{Prob}($ F-stat) $\quad .000$

Table 14 showed the summary of multiple regression results for the effects of quality of investment in terms of macro-fundamental, governance and infrastructure. Having probability value of fstatistics is .000 the whole econometric model is reflected as significant. The value of $r$-square which is .476 indicates that 47.60 percent of the variation of attractiveness of tourism industry in CALABARZON can be explained by the changes in the quality of investment. The value of yintercept .571 holding other variables constant. This means that .571 percent will be increased in attractiveness value if the quality of investment are equal to zero. The coefficient of macrofundamental, governance and infrastructure are all positive which implies that an increase in the quality of investment will promote attractiveness of tourism industry in terms of geographical proximity.

Geographical distance has an ambiguous role. On one hand, it can be taken as a proxy of change obstacles (tariff and non tariff barriers, transport costs), in the equal way as the products' exchange, the FDI relies upon on the distance between the two countries. Accordingly, pursuant to the horizontal model, FDI flows are predicted to grow with the distance between investor and host nations and, in a vertical model, distance performs a function of repulsion. Conversely, the presence of cultural and felony differences can be an impediment to the establishment of overseas firms in a nation. (and therefore to the look of FDI inflows). In this case, the expected effect of the distance is negative. (Saidi, 2016)

\section{Proposed Business Operations Initiative}

This section discussed the proposed business operations initiative for the CALABARZON region. A proposed business operations initiative was created in order to encourage each and every stakeholders of the tourism industry to be more active participant in improving the services offered in the Tourism industry of CALABARZON. From the lowest assessment of the respondents, the researcher had focused in that aspect to develop the operations initiative that will benefit both the community and the tourism industry practitioner to grow more and build good harmonious relationship with each other. Also, this will be a good avenue in improving the quality of services that are offered in the region and will be a good tool in making the region more competitive to the tourism industry of the other regions in the Philippines. Finally, this will ensure the tourists a more convenient and accessible tourism industry particular those first hand services that are needed by them in ensuring that they will have a good experience in visiting the CALABARZON region. 
Table 15: Proposed Business Operations Initiative

\begin{tabular}{|c|c|c|c|c|c|}
\hline \multicolumn{2}{|c|}{ Key Result Area } & \multirow{2}{*}{ 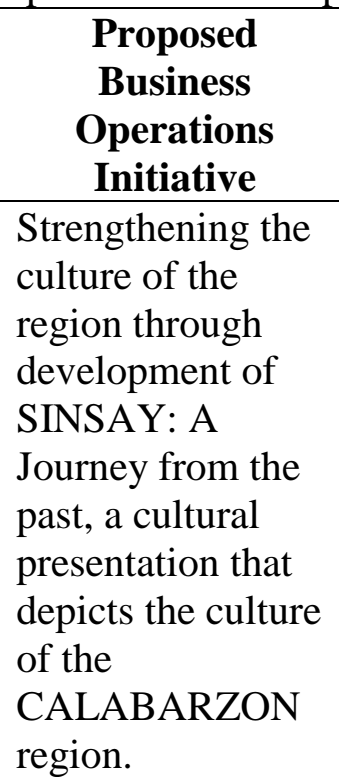 } & $\begin{array}{c}\text { Time } \\
\text { Frame }\end{array}$ & \multirow{2}{*}{$\begin{array}{l}\text { Persons } \\
\text { Involved } \\
\\
\text { Local } \\
\text { Government }\end{array}$} & \multirow{2}{*}{\begin{tabular}{|l}
\multicolumn{1}{|c|}{ Outcomes } \\
$\begin{array}{l}\text { Increased of } \\
\text { tourists } \\
\text { awareness in } \\
\text { the culture } \\
\text { and history } \\
\text { of the } \\
\text { region. }\end{array}$
\end{tabular}} \\
\hline \multirow[t]{3}{*}{$\begin{array}{l}\text { Attractiveness of } \\
\text { CALABARZON } \\
\text { Region }\end{array}$} & $\begin{array}{l}\text { Cultural } \\
\text { Proximity }\end{array}$ & & $\begin{array}{l}2 \\
\text { months }\end{array}$ & & \\
\hline & $\begin{array}{l}\text { Destination } \\
\text { Environment }\end{array}$ & $\begin{array}{l}\text { Improving tourism } \\
\text { information } \\
\text { program through } \\
\text { wide } \\
\text { dissemination and } \\
\text { exhibition of } \\
\text { tourist products } \\
\text { and services } \\
\text { through creation } \\
\text { of websites and } \\
\text { social media sites. }\end{array}$ & $\begin{array}{l}5 \\
\text { months }\end{array}$ & \multirow{3}{*}{$\begin{array}{l}\text { Local } \\
\text { Government } \\
\text { Local } \\
\text { Resident } \\
\text { Other } \\
\text { Tourism } \\
\text { Stakeholders }\end{array}$} & $\begin{array}{l}\text { Well } \\
\text { informed } \\
\text { tourists to } \\
\text { the different } \\
\text { information } \\
\text { of tourist } \\
\text { destinations } \\
\text { in the region. }\end{array}$ \\
\hline & Price & $\begin{array}{l}\text { Enhancement of } \\
\text { affordable prices } \\
\text { through advanced } \\
\text { study of the } \\
\text { competition in } \\
\text { nearby regions for } \\
\text { tourist retention. }\end{array}$ & $\begin{array}{l}3 \\
\text { months }\end{array}$ & & $\begin{array}{l}\text { Improved } \\
\text { restaurant } \\
\text { prices are } \\
\text { competitive } \\
\text { enough } \\
\text { when to } \\
\text { compare to } \\
\text { other } \\
\text { regions. }\end{array}$ \\
\hline $\begin{array}{l}\text { Attractiveness of } \\
\text { CALABARZON } \\
\text { Region }\end{array}$ & $\begin{array}{l}\text { Destination } \\
\text { Image }\end{array}$ & $\begin{array}{l}\text { Improving } \\
\text { accessibility and } \\
\text { through } \\
\text { collaboration of } \\
\text { the different } \\
\text { tourism } \\
\text { stakeholders. }\end{array}$ & $\begin{array}{l}8 \\
\text { months }\end{array}$ & & $\begin{array}{l}\text { Easy access } \\
\text { of tourists to } \\
\text { different } \\
\text { destinations } \\
\text { and a } \\
\text { renowned } \\
\text { historical } \\
\text { destination }\end{array}$ \\
\hline
\end{tabular}




\begin{tabular}{|c|c|c|c|c|c|}
\hline & & & & & $\begin{array}{l}\text { for the } \\
\text { region. }\end{array}$ \\
\hline & $\begin{array}{l}\text { Risk and } \\
\text { Reward }\end{array}$ & $\begin{array}{l}\text { Joint force } \\
\text { collaboration of } \\
\text { disaster response } \\
\text { team of the } \\
\text { government } \\
\text { through safety and } \\
\text { response training } \\
\text { and providing } \\
\text { necessary } \\
\text { equipment for the } \\
\text { service. }\end{array}$ & $\begin{array}{l}2 \\
\text { months }\end{array}$ & & $\begin{array}{l}\text { A well- } \\
\text { prepared } \\
\text { tourist } \\
\text { destination } \\
\text { in case of } \\
\text { disaster } \\
\text { response } \\
\text { through } \\
\text { easily } \\
\text { available } \\
\text { equipment } \\
\text { and well- } \\
\text { trained } \\
\text { personnel }\end{array}$ \\
\hline $\begin{array}{l}\text { Attractiveness of } \\
\text { CALABARZON } \\
\text { Region }\end{array}$ & $\begin{array}{l}\text { Geographical } \\
\text { Proximity }\end{array}$ & $\begin{array}{l}\text { Enhancement of } \\
\text { the transportation } \\
\text { sector by } \\
\text { increasing its } \\
\text { availability to and } \\
\text { from different } \\
\text { tourist destinations } \\
\text { in the region. }\end{array}$ & $\begin{array}{l}4 \\
\text { months }\end{array}$ & $\begin{array}{l}\text { Local } \\
\text { Government } \\
\text { Local } \\
\text { Resident } \\
\text { Other } \\
\text { Tourism } \\
\text { Stakeholders }\end{array}$ & $\begin{array}{l}\text { Easy access } \\
\text { of tourists to } \\
\text { different } \\
\text { destinations } \\
\text { at anytime. }\end{array}$ \\
\hline
\end{tabular}

Gantt Chart of Proposed Business Operations Initiative

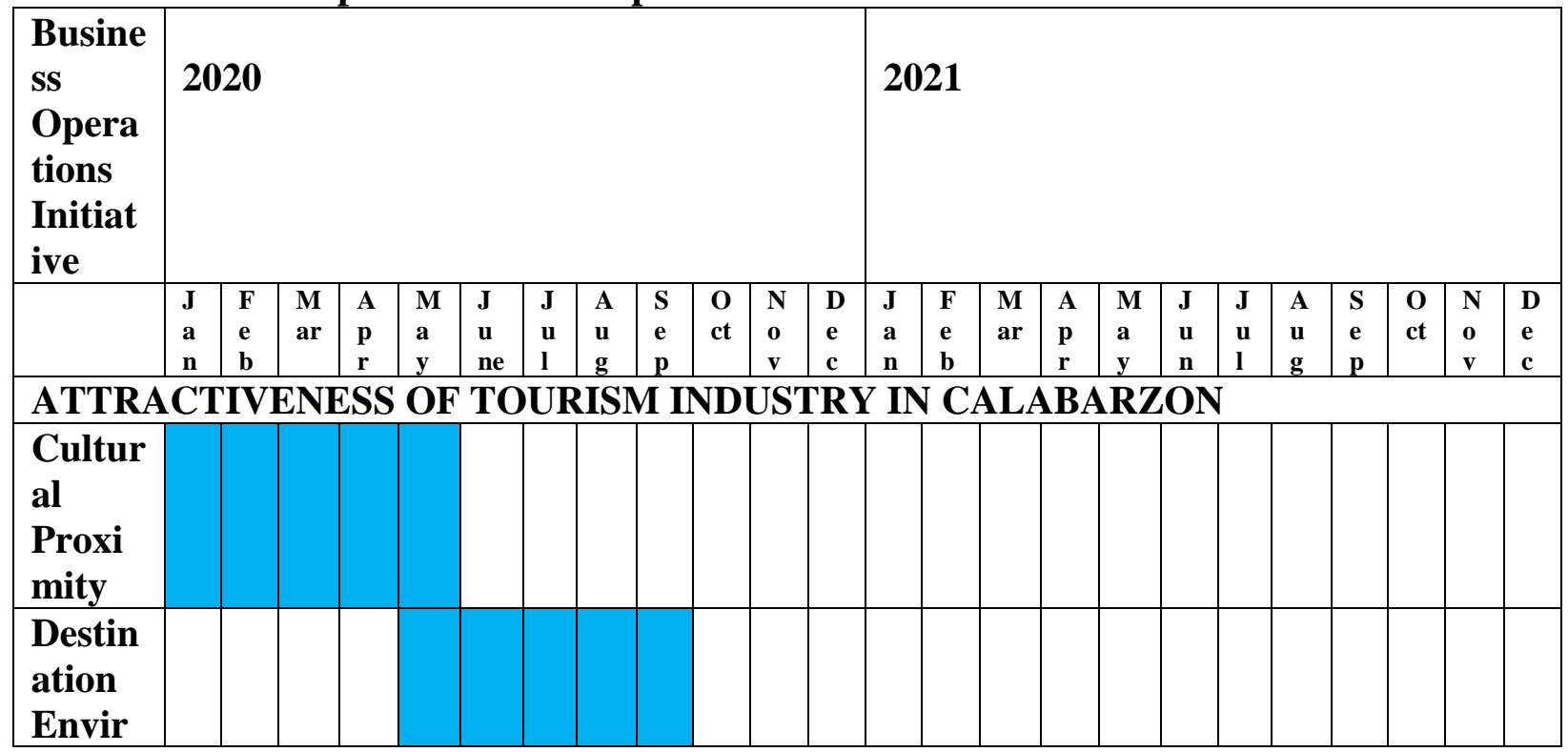




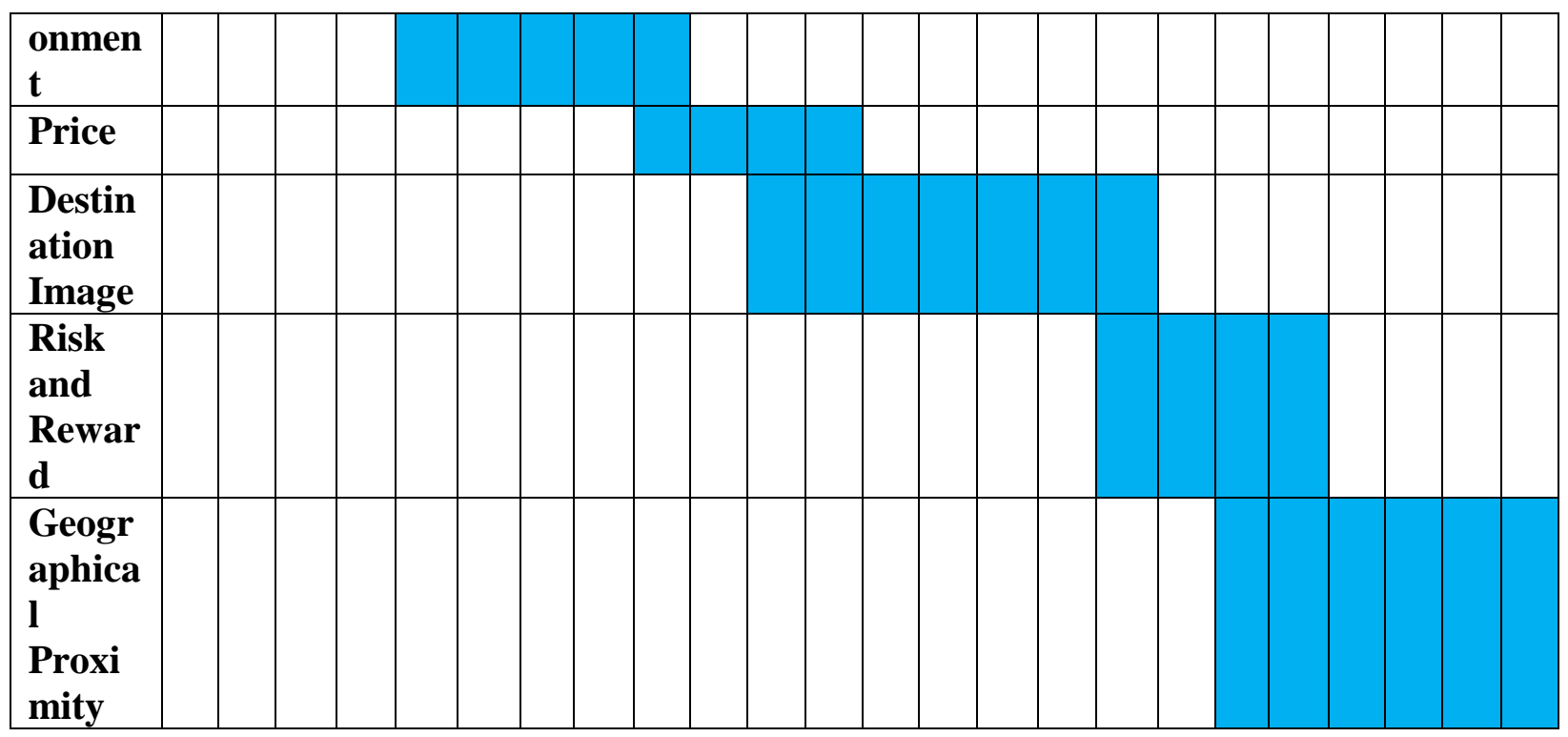

\section{Conclusions}

1) Majority of the respondents belonged to the age bracket of 18-35 years old, female, single, college graduate and has an income ranging from Php 10,001.00 - Php 25,000.00.

2) The tourists, local residents and local government unit all agreed that CALABARZON region is moderately attractive to tourists having the existence of different tourism related establishments that provide good services and competitive tourist destinations that can be compared to other region in the country.

3) Investment climate has an effect on the attractiveness of the tourism industry in CALABARZON region.

4) A business operations initiative was proposed to make the investment climate and tourism industry of CALABARZON region more competitive enough and to keep abreast with the demand of the industry itself.

\section{Recommendations}

1) Strengthening the culture and history of the region may be increased through different cultural presentations that depicts the treasure of CALABARZON region engulfed in its traditions and customs.

2) Products and services offered of the tourist destinations may be enhanced through trade fair and exhibition in improving tourist information and gaining knowledge of the tourists.

3) Competitive prices may be enhanced through advanced studies of the status of competition in nearby regions to ensure competitiveness of the tourism industry and tourist retention.

4) Increased accessibility to tourist destinations may be achieved through maintenance of different roads and bridges to and from different destinations to ensure that each of then can be reached conveniently.

5) Safety and security measures to tourist destinations may be increased through collaboration with the disaster response group of the government in ensuring that safety equipment are available to different tourist destinations in case of emergency. 
6) Increased availability of transportation to and from the different tourist destinations may be enhanced through partnerships with different transport sector in providing a 24-hour service for the convenience of the tourists.

7) Proposed business operations initiative to make the CALABARZON region more competitive enough and abreast to the demand of the industry may be implemented.

\section{Acknowledgements}

The researcher acknowledges his sincerest gratitude and appreciation to the following people for making this thesis possible:

- To Dr. Norma L. Meñez, Dean of the Graduate School and the thesis adviser for her motherly concern and professional assistance;

- To his thesis panel; Dr. Mark Irvin C. Celis, Dr. Alex P. Ylagan and Dr. Sevilla S. Felicen for their intellectual and scholarly examination of the research;

- To all research respondents from the different places in CALABARZON, for answering the questionnaire patiently and accurately;

- To the librarians and staff of two universities, Batangas State University and Lyceum of the Philippines University - Batangas, for providing related documents needed in the research;

- To Ms. Annalie Pateña, statistician for her valuable time in the computation and analysis of the statistical part of the study;

- To Dr. Sevilla S. Felicen, research professor, for the advices, intellectual debates and academic wisdom;

- To his co-graduates students, for their friendship and wonderful times;

- To all of the researcher relatives and friends; infinite thanks and appreciation to you all;

- To Valdez and Cruzat family, for their support and gratitude;

- To his parents, Mr. Jose E. Valdez+ and Mrs. Irene C. Valdez, for their unwavering care and understanding;

- To the faculty of CABEIHM-BatStateU for the help and support to the researcher;

- To the faculty of MIHM, for their guidance and additional knowledge;

- To God Almighty, for unconditional love, care and blessings that He had given to the researcher for the pursuant of this study.

\section{Appendices}

\section{Survey Questionnaire}

\section{Investment Climate and Attractiveness of Tourism Industry in CALABARZON: Basis for Tourism Development Plan}

Name (optional):

\section{Profile of the respondents}

Direction: Put check $(\sqrt{ })$ on the space provided that corresponds to your answer. Age 18-35 years old 36-55 years old 
56 years old and above

Sex

Male

Female

Civil Status

Single

Married

Widow/ Widowed/ Separated

Educational Attainment

Elementary Graduate

High School Graduate

Technical/ Vocational Graduate

College Graduate

Post Graduate

Monthly Income

below Php 10,000.00

Php 10,001.00 - Php 25,000.00

Php 25,001.00 - Php 50,000.00

Php 50,001.00 and above

\section{Quality of Investment Climate of Tourism Industry in Region IV-A.}

Direction: Kindly put check mark $(\sqrt{ })$ on the column that corresponds to your choice.

4 - Strongly Agree/ Highly Attractive

3 - Agree/ Moderately Attractive

2 - Disagree/ Less Attractive

1 - Strongly Disagree/ Not Attractive

Cultural Proximity - is composed of such specific things like "humor, gender, images, dress, lifestyle, knowledge about other lifestyles, ethnic types, religion, and values."

\begin{tabular}{|c|c|c|c|c|}
\hline \multirow{2}{*}{\multicolumn{5}{|c|}{$\begin{array}{l}\text { Items } \\
\text { The local people has distinct language spoken almost everywhere. }\end{array}$}} \\
\hline & & & & \\
\hline $\begin{array}{l}\text { Verbal communication and signage instructions are well represented by the } \\
\text { local dialect of the place. }\end{array}$ & & & & \\
\hline Religious activities such as processions are observable and well celebrated. & & & & \\
\hline Festivals are celebrated in honor of their patron saint. & & & & \\
\hline Bayanihan is well observed through the local people. & & & & \\
\hline Tourist destination offers local delicacies for the tourists. & & & & \\
\hline Cultural shows and presentations are observable and well presented. & & & & \\
\hline Local foods and dishes are served to tourists in restaurants and hotels. & & & & \\
\hline Religious churches are visible and well maintained. & & & & \\
\hline $\begin{array}{l}\text { Local made products especially handmade products are available for the } \\
\text { purchase of the tourists. }\end{array}$ & & & & \\
\hline
\end{tabular}

Destination Environment - include those factors that may enhance attractiveness for the tourists. 
The climate in the tourist destinations is fine.

Tourist destinations are surrounded by trees and plants.

The cultural and historical sites' architecture is distinct and attractive from each other.

Everything inside the tourist destination is well exhibited, providing tourist sufficient information in order to gain knowledge.

Tourist destinations are free from noise providing relaxing ambiance for the visitors.

Tourist destinations are clean and well maintained.

The local community around the tourist destinations are hospitable and welcoming.

Tourist destinations has complete facilities and amenities for the needs of the tourists.

Tourist destinations has scenic view and natural attractions.

Tourist destinations has facilities for reflections and meditation.

Price - is the quantity of payment or compensation given by one party to another in return for one unit of goods or services.

\section{Items}

Tour packages prices are reasonable.

Accommodation rates compliments with the facilities and amenities offered.

Transportation fares to and from the tourist destinations are enough and affordable.

Entrance fees are affordable.

Rental fees such as vans and equipment usage are not high and services provided is well compensated.

Restaurants offers affordable prices of food especially local delicacies.

Prices posted on websites are the actual prices offered in the tourist destinations.

The prices of tourist products compliment with the actual service given.

There are promos offered on prices such as discounts and freebies.

Tour guides rates is enough to the given services.

\begin{tabular}{|l|l|l|l|l|} 
& $\mathbf{4}$ & $\mathbf{3}$ & $\mathbf{2}$ & $\mathbf{1}$ \\
\hline & & & & \\
\hline & & & & \\
\hline & & & & \\
\hline & & & & \\
\hline & & & & \\
\hline & & & & \\
\hline & & & & \\
\hline & & & & \\
\hline & & & & \\
\hline
\end{tabular}

Destination Image - refers to the physical environment that includes natural and manmade components.

\begin{tabular}{|c|c|c|c|c|}
\hline Items & 4 & 3 & 2 & 1 \\
\hline Tourist destinations depicts the rich culture of the place. & & & & \\
\hline Tourist destinations are spacious for the tourists to easily roam around. & & & & \\
\hline Accommodation establishments are well-ventilated and has a good ambiance. & & & & \\
\hline $\begin{array}{l}\text { Roads and bridges going to and from the different tourist destinations are firm and } \\
\text { in-tact. }\end{array}$ & & & & \\
\hline $\begin{array}{l}\text { Adobe rocks and foundation of historical churches stand still and free from } \\
\text { danger. }\end{array}$ & & & & \\
\hline Historical houses are well-maintained and preserved. & & & & \\
\hline $\begin{array}{l}\text { Natural attractions depicts healthy environment with vibrant colors from plants } \\
\text { and trees. }\end{array}$ & & & & \\
\hline
\end{tabular}


Water from the rivers and lakes are clear and clean and good for swimming.

Tourist destinations are well-maintained and properly managed.

Tourist destinations clearly depicts the historical background of the place.

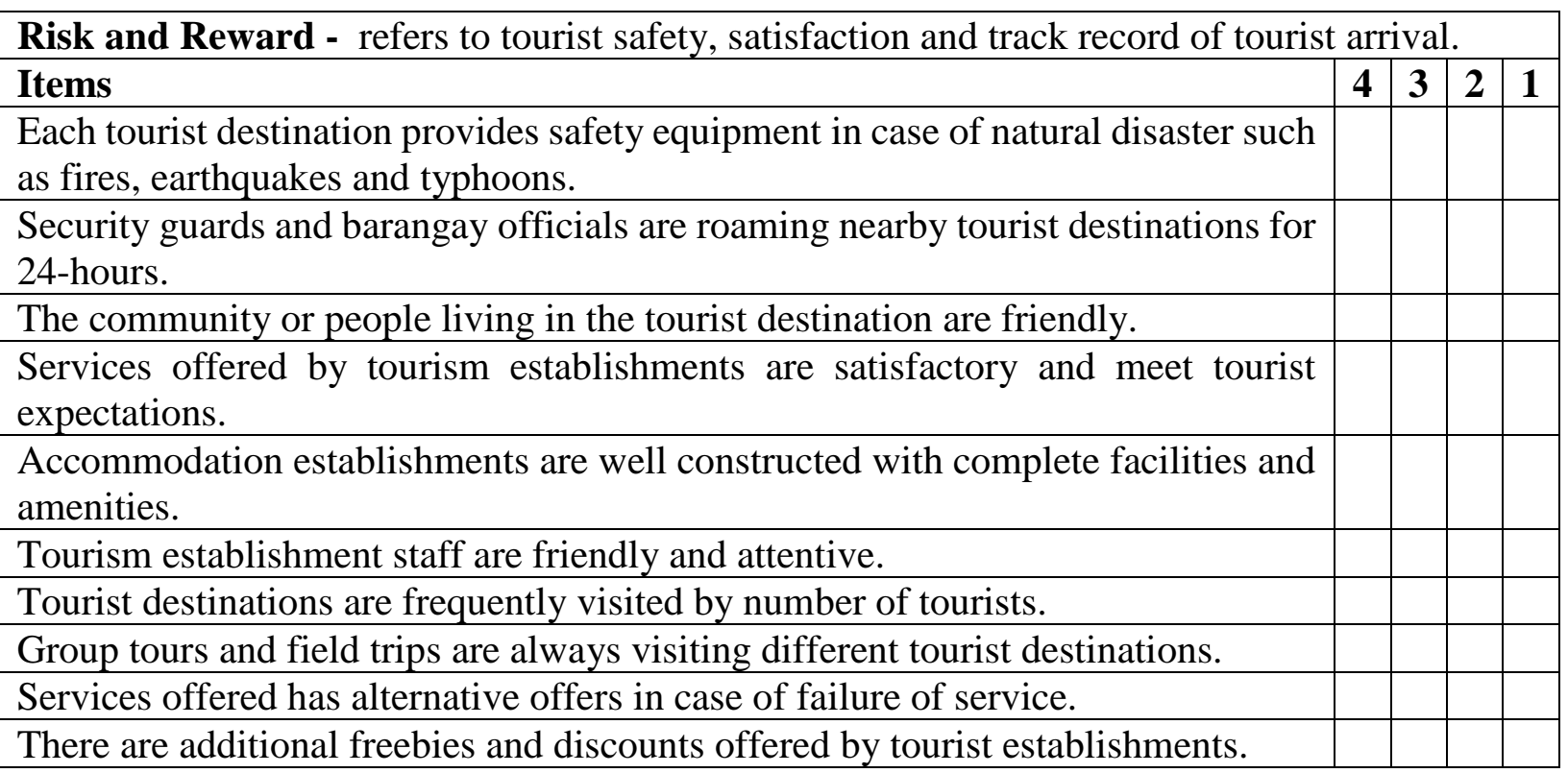

Geographical Proximity - means how easy a place is for the tourist to access or get to the desired destination.

\begin{tabular}{|c|c|c|c|c|}
\hline Items & 4 & 3 & 2 & 1 \\
\hline Road signages are present and can be easily seen by tourist. & & & & \\
\hline $\begin{array}{l}\text { Full information about the facilities, terminal location and local transportations } \\
\text { are made available to all passengers and tourists. }\end{array}$ & & & & \\
\hline Tourist destinations uses different transportation such as tricycle, jeep and boat. & & & & \\
\hline $\begin{array}{l}\text { There are regular trip going to and from the different destinations that is } 24 \text {-hour } \\
\text { available to the public. }\end{array}$ & & & & \\
\hline Jeepney, tricycle and boat fares are at reasonable prices. & & & & \\
\hline The transportation to-and-from the tourist destinations is far from the city. & & & & \\
\hline $\begin{array}{l}\text { Complete information of fares, schedules and route of local transportation is } \\
\text { provided. }\end{array}$ & & & & \\
\hline Boundary markers are constructed/ installed. & & & & \\
\hline $\begin{array}{l}\text { The road to and from the different tourist destinations is firmly constructed with } \\
\text { cement. }\end{array}$ & & & & \\
\hline $\begin{array}{l}\text { Road to and from the different tourist destinations is accessible to all types of } \\
\text { vehicles. }\end{array}$ & & & & \\
\hline
\end{tabular}

\section{References}

[1] Cruz, Z. L. Principles of Tourism Part II. Rex Bookstore. Manila Philippines. 2011.

[2] Tamayo, M. J. M. What is Governance? Laws, Politics and Philosophy. Retireved from: https://tamayaosbc.wordpress.com/2014/08/21/what-is-governance/. 2014.

[3] Lubiano, A. L. Discover Ideas about Consumer Culture. Retrieved from: 
https://www.pinterest.ph/pin/305681893427273456/.2016

[4] Malibiclibic Falls, A Hidden Falls below the grasslands of Cavite. Retrieved from: http://www.slexpeditions.com/2013/07/089-malibiclibic-cavite.html.2013.

[5] You, S. H., Gung, Y., Lin, C. H., Konstantinou, K. I., Chang, T. M., Chang, E. T. Y., and Solidum, R. A Preliminary Seismic Study of Tall Volcano, Luzon Island Philippines. 2012.

[6] Masasa Beach on a Budget: Travel Guide \& Itinerary. Retrieved from: https://www.thepoortraveler.net/2017/03/masasa-beach-travel-guide/. 2017.

[7] Velasco, J. M. Hats off to Sombrero Island. Retrieved from: http://www.marxtermind.com/hatsoff-to-sombrero-island/. 2013.

[8] Abella, J. K., Boo, J. M., Cuidad, V. D., De Guzman, M. K. J., Deomampo, J. S. and Espiritu, S. D. I. The Status and Problems of Selected Beach Resorts in Mabini, Batangas. 2014.

[9] Dalisay, V. J. C. Ecotourism Development of Mount Maculot in Cuenca, Batangas. 2015.

[10] Lasco, G. Mt. Daraitan. Retrieved from: http://www.pinoymountaineer.com/2014/10/mt-daraitan739.html. 2014.

[11] Masungi Georeserve. Retrieved from: https://www.masungigeoreserve.com/. 2018.

[12] Balaoing, J. Experience the Philippines with Salibungot Beach. Retrieved from: http://www.herjcjane.com/2017/06/experience-philippines-with-salibungot.html. 2017.

[13] Kanaway: The Sunrise Beach of Jomalig Island. Retrieved from: http://www.s1expeditions.com/2013/04/068-kanawaybeach-quezon.html. 2013.

[14] The Impact of Culture on Tourism. Retrieved from: http://www.liaa.gov.lv/files/liaa/attachments/turisms/petijumi/OECD_Tourism_Culture.pdf. 2012.

[15] What is Flora and Fauna? Retrieved from: https://www.conserve-energy-future.com/what-areflora-and-fauna.php. 2011.

[16] Heung, V., Zhang, H., Jiang, C. International franchising: opportunities for China's state-owned hotels? International Journal of Hospitality Management 27 (3), 368-380. 2015.

[17] Childs, C. How Culture and Heritage Tourism Boost more than a Visitor Company. Retrieved from: https://www.mytravelresearch.com/culture-and-heritage-tourism-boosts-visitor-economy/. 2018.

[18] Kusluvan, S., Kusluvan, Z., Ilhan, I. \& Buyruk, L. The human dimension: a review of human resources management issues in the tourism and hospitality industry. Cornell Hospitality Quarterly, 51(2):171-214. 2015.

[19] Kankochiikidukuri- Annaihyoshikikenkyukai. Retrieved from: 07.3.2010]. Available in wwwform: <URL: http://www.mlit.go.jp/common/000059348.pdf>. 2015.

[20] Stabler, J., \& Goodal, B. Environmental awareness, action and performance in the Guernsey hospitality sector. Tourism Management, 18(1), 19\}33. 2017.

[21] UNCTAD. Tourism Investment and Finance. Retrieved 2010 from: https://www.usaid.gov/sites/default/files/documents/2151/InvestmentWorkbook_4\%5B2\%5D.pd

[22] Dwyer, L., Forsyth, P., \& Dwyer, W. Tourism Economics and Policy. Channel View Puplications. 2010.

[23] Dupeyras, A. and MacCallum, N. Indicators for Measuring Competitiveness in Tourism. Retrieved from: https://www.oecd.org/cfe/tourism/Indicators\%20for\%20Measuring\%20Competitiveness\%20in\% 20Tourism.pdf. 2013.

[24] Saidi, S. Territorial Attractiveness of the Foreign Direct Investment: Empirical Evidence from Panel Data Analysis for the Case of Tunisia. 2016.

*Corresponding author.

E-mail address: elroyjoseph_valdez0913@yahoo.com 